\title{
Uncovering the Origins of the Gender Gap in Political Ambition
}

\author{
RICHARD L. FOX Loyola Marymount University \\ JENNIFER L. LAWLESS American University
}

\begin{abstract}
$B$ ased on survey responses from a national random sample of nearly 4,000 high school and college students, we uncover a dramatic gender gap in political ambition. This finding serves as striking evidence that the gap is present well before women and men enter the professions from which most candidates emerge. We then use political socialization - which we gauge through a myriad of socializing agents and early life experiences - as a lens through which to explain the individual-level differences we uncover. Our analysis reveals that parental encouragement, politicized educational and peer experiences, participation in competitive activities, and a sense of self-confidence propel young people's interest in running for office. But on each of these dimensions, women, particularly once they are in college, are at a disadvantage. By identifying when and why gender differences in interest in running for office materialize, we begin to uncover the origins of the gender gap in political ambition. Taken together, our results suggest that concerns about substantive and symbolic representation will likely persist.
\end{abstract}

\section{UNCOVERING THE ORIGINS OF THE GENDER GAP IN POLITICAL AMBITION}

F or decades, one question has guided much of the research on gender and elections in the United States: Why do so few women occupy elective office? In an attempt to answer this question, gender politics scholars have employed a multifaceted and eclectic approach. They have surveyed and interviewed candidates and elected officials to assess levels of discrimination against women. They have combed fundraising receipts and vote totals to determine how women fare in the electoral arena. They have analyzed institutional barriers, such as the incumbency advantage and women's presence in the professions that lead to political careers, to uncover structural obstacles women face. Yet when the $113^{\text {th }}$ Congress convened in January 2013, $82 \%$ of its members were men. This places the United States $95^{\text {th }}$ worldwide in the percentage of women serving in the national legislature (Inter-Parliamentary Union 2013). Thus, despite women's gains in the educational and professional spheres that precede a career in politics, as well as evidence that points to broad public acceptance of female candidates, women remain significantly under-represented at all levels of elective office in the United States (for a review, see Lawless and Fox 2010; Palmer and Simon 2008).

This paradox has led scholars to identify the candidate emergence process as one the biggest obstacles to women's numeric representation (e.g.,Carroll 1994; Sanbonmatsu 2002). Indeed, data from the Citizen Political Ambition Studies - three national surveys of

Richard L. Fox is Professor, Department of Political Science, Loyola Marymount University, 1 LMU Drive, Los Angeles, CA 90045 (richard.fox@lmu.edu)

Jennifer L. Lawless is Professor, Department of Government, American University, 4400 Massachusetts Avenue, NW, Washington, DC20016 (lawless@american.edu)

For comments on previous versions of this article, we thank Gail Baitinger, Kathy Dolan, Danny Hayes, Andrew Healy, Kent Jennings, Sue Tolleson-Rinehart, Matt Wright, and seminar participants at Duke University's Political Behavior Workshop and the Kennedy School's series on women and public policy. This research was funded by the National Science Foundation (Grant No. 115405). women and men who work in the professions from which most candidates for elective office emergereveal a striking gender gap in political ambition (Lawless and Fox 2012; 2010; 2005). Women are less likely than similarly situated men to consider running for office; less likely to run for office; less like to believe they are qualified to seek office; less likely to receive encouragement to run for office; and more likely to perceive a competitive, biased electoral environment (see also Fulton et al. 2006).

Although the existing work on candidate emergence identifies and explicates the contours of the gender gap in political ambition among well-established potential candidates, virtually no political science research examines its origins (but see Elder 2004). We are very limited in the conclusions we can draw about the roots of the gap or the manner in which early life experiences shape it. This omission in the literature is critical because a general interest in, or openness toward, running for office early in life can set the stage for a political candidacy decades later. Young people's career goals, after all, tend to be excellent predictors of the occupations they ultimately attain (Ashby and Schoon 2010; Mello 2008; Trice and McClellan 1993). Many gendered attitudes about running for office, then, may result from deeply embedded socialized norms that are conveyed long before women and men find themselves in the candidate eligibility pool. Yet we simply do not know when young women and men's political ambition diverges, the extent to which it does so, or the factors that contribute to it. If the seeds of political ambition are planted at an early age, then gaining a complete understanding of the gender gap in ambition and prospects for women's representation demands that we pinpoint and explicate its origins.

This article provides the first investigation to do just that. Based on survey responses from a national random sample of nearly 4,000 high school (ages 13 to 17) and college (ages 18 to 25) students, we uncover a substantial gender gap in political ambition. This is striking evidence that the gap is, in fact, present well before women and men enter the professions from which most candidates emerge. We then employ 
political socialization - which we gauge through a myriad of socializing agents and early life experiences - as a lens through which to explain the individual-level differences we uncover. Our analysis reveals that parental encouragement, politicized educational and peer experiences, participation in competitive activities, and a sense of self-confidence influence young people's interest in running for office. But on each of these dimensions, women, particularly once they are in college, are at a disadvantage. By identifying when and why gender differences in interest in running for office materialize, we begin to uncover the origins of the gender gap in political ambition. Taken together, our results suggest that concerns about substantive and symbolic representation will likely persist. ${ }^{1}$

\section{STUDYING POLITICAL AMBITION EARLY IN LIFE: THE RESEARCH DESIGN}

For the last forty years, scholars have provided compelling evidence of the transmission of political attitudes and activism through key agents of political socialization, such as family, education, peer associations, and media (for a review, see Jennings 2007; Sapiro 2004; Stoker and Bass 2011). Studies that investigate the manner in which socializing agents among youth populations affects political behavior, however, do not examine political ambition. Our canvass of the major data sets available - from a variety of disciplines and archived through both ICPSR and Roper-uncovered no existing questions about young people's interest in running for office as a career goal or aspiration. So, even though the extant research can shed light on the relationship between early socialization and many types of political attitudes and behavior, it cannot speak to political ambition or the role gender plays in its formation. $^{2}$

\footnotetext{
${ }^{1}$ Women's numeric under-representation carries serious consequences for the quality of political representation and democratic legitimacy. Scholars have uncovered evidence that male and female legislators' priorities and preferences differ (e.g., Gerrity, Osborn, and Mendez 2007; Mendez and Osborn 2010; Swers 2002; Thomas 1994); and that women's inclusion infuses into the legislative system a style of leadership that emphasizes congeniality and cooperation, as opposed to hierarchy (Kathlene 1994; Rosenthal 1998; Weikart et al. 2007). They also point to symbolic effects that women's presence in positions of political power confers to female citizens (see Mansbridge 1999).

2 Two national surveys have asked young adults about their interest in running for office. A 2009 survey of students taking the Law School Admission Test revealed that male and female pre-law students had similar life goals, such as earning money and having a family. But women were only half as likely as men to report that they would "definitely" consider using a law degree as a stepping stone to a political career in the future. A 2003 study of 18 to 24 year old college students uncovered similar findings. Although these data suggest that the gender gap in political ambition is in place by young adulthood, neither survey included questions that allow for an analysis of the origins of gender differences in interest in running for office. The only study that begins to delve more deeply into political ambition among young people is a survey of junior high school, high school, college, and adult samples in one county in central New York (Elder 2004). Variations in the gender gap in ambition among the four subsamples are linked to traditional socialization, self-confidence, and the presence of role models. Although an important first step, this study's
}

Whereas the literature pertaining to early socialization does not consider political ambition, the candidate emergence literature is limited in uncovering the origins of the gender gap for at least two reasons of its own. First, it focuses on samples of adults who are already established professionally. In most cases, respondents are actual candidates and office holders, all of whom, by definition, exhibited political ambition when they entered their first political contest (e.g., Canon 1993; Gaddie 2004; Maestas et al. 2006). But even the research that analyzes potential candidates relies exclusively on adults' retrospective assessments of their early life experiences (Lawless and Fox 2010; 2005; see also Stone and Maisel 2003). Scholars of political psychology and attitude formation, however, warn about the substantive and methodological problems involved in relying on survey questions that ask people to reflect on previous time periods. Analyses of panel data show, for example, that recollections about political beliefs "correspond poorly to attitudes as originally expressed" (Markus 1986, 41-2). Further, well-documented errors in the relationship between memory and self-such as absent-mindedness, misattribution, and bias-can frequently lead to versions of past life experiences that do not accurately reflect reality (Schacter 1999; see also Schacter, Chiao, and Mitchell 2003).

Second, even if we are cautious when interpreting reflections of previous experiences, the age distribution of women and men in the candidate eligibility pool limits the light the data can shed on when the gender gap in ambition emerges. The average age of the potential candidates in the Citizen Political Ambition Studies is 50 years old. So, although the 2011 survey reveals a gender gap in ambition among respondents under the age of 35 (Lawless and Fox 2012), and the 2001 survey uncovers a gender gap in ambition that is largest among those under the age of 40 (Lawless and Fox 2005), these cohort analyses are based on small samples. Moreover, hardly any of the respondents are younger than 30 .

To investigate the relationship between early life experiences and the gender gap in political ambition, it is critical to survey respondents at a time that is more proximate to the original formation of attitudes about running for office. Thus, we conducted the first national survey of high school and college students' political ambition. From September 27 to October 16, 2012, we surveyed a national random sample of 1,121 male and 1,042 female high school students (ages 13 to 17 ) and 1,020 male and 1,097 female college students (ages 18 to 25). ${ }^{3}$ The survey allowed for an in-depth examination

generalizability is limited, not only because of geography, but also because of a small sample size (there are fewer than 90 respondents in each of the junior high and high school student subsamples).

${ }^{3}$ In carrying out this study, we contracted with GfK Custom Research LLC (formerly Knowledge Networks), which relies on a probability-based online nonvolunteer access panel. Panel members are recruited using a statistically valid sampling method with a published sample frame of residential addresses that covers approximately $98 \%$ of U.S. households. The sample consists of about 50,000 adult members (ages 18 and older), including people who live in cell phone only households. The sample also includes approximately 3,000 teens, ages 13 to 17 , whose parents or guardians provided 
of whether a gender gap in political ambition exists among young people, as well as the factors that might contribute to or sustain it. More specifically, we designed the survey so that we could operationalize the effects of political socialization on political ambition.

Important for our purposes, the male and female respondents were very similar in terms of race, religion, household income, region, and age (see Appendix A). As expected, women were slightly more likely than men to identify as Democrats, whereas men were more likely than women to identify as Republicans. But the few statistically significant gender differences within the sample were substantively small (and our multivariate analyses control for them). Accordingly, any gender gap in political ambition that we uncover does not result from sociodemographic differences between male and female respondents. ${ }^{4}$

\section{ESTABLISHING THE GENDER GAP IN EARLY POLITICAL AMBITION}

Similar to most adults, the majority of young people do not envision running for office. Among those who do, however, there is a substantial gender gap. Young women and men are not equally politically ambitious. We asked our respondents whether they ever thought that, someday, when they were older, they might want to run for any political office. Forty-one percent stated that the idea of running for an elective position had at least "crossed their mind." The data presented in Figure $1 \mathrm{~A}$, however, reveal that men were almost twice as likely as women to have thought about running for office "many times," whereas women were roughly $20 \%$ more likely than men never to have considered it. Put somewhat differently, $35 \%$ of women, compared to $48 \%$ of men, considered running for office. When we turn to the question of young people's plans to run for office in the future, the gender differences are just as stark. Men were two-thirds more likely than women to report that they "definitely" plan to run for office at some point in the future. Women, on the other hand, were $45 \%$ more likely than men to assert that they would never run (see Figure 1B).

These gender differences are notable, but the notion of running for office may seem very far off in the minds

consent, as well as several thousand individuals between the ages of 18 and 25 who are enrolled in college. In our case, panel members were supplemented with a companion sample of respondents from an opt-in web panel. The same screening criteria were used for both sample sources to identify the eligible sample for the survey, as well as to calibrate the surveys from the nonprobability sample source and correct for sampling error and self-selection bias in the nonprobability web panels.

${ }^{4}$ We restrict the sample to college students and the $83 \%$ of high school students who plan to attend college. Although the results of our analyses are generally comparable when we include the entire high school sample, the restricted sample is a better representation of what the next generation of potential candidates will look like; the overwhelming majority of elected officials at both the state and federal level hold college degrees. In fact, not one respondent - male or female-among the $17 \%$ of high school students who did not plan to attend college expressed "definite interest" in running for office in the future. of high school and college students. Accordingly, we also asked respondents a series of questions about jobs they would most like to hold in the future. And here, too, our results reveal gender differences in political ambition.

In a first scenario, we presented respondents with four career options - business owner, teacher, mayor of a city or town, and salesperson-and asked them which they would most like to be, assuming that each paid the same amount of money. Although both women and men ranked owning a business and being a teacher as more desirable than serving as a mayor, men were almost two-thirds more likely than women to select mayor as their preferred job (see Figure 2A). When we asked respondents to indicate which of the four positions they would least like to hold, a substantial gender gap emerged as well: $43 \%$ of women, compared to $31 \%$ of men, reported that mayor was their least preferred profession (this was the top answer for women).

We then asked respondents to indicate which of the following four higher echelon jobs they found most appealing: business executive, lawyer, school principal, or member of Congress. Once again, women were significantly more likely than men to eschew the possibility of a political career. The data presented in Figure 2B reveal that men were $60 \%$ more likely than women to select a position as a member of Congress. On the other hand, $43 \%$ of women, compared to $33 \%$ of men, reported that serving in Congress was the least desirable professional option.

As a third way to gauge political ambition, we provided respondents with a list of 24 jobs and asked them to check off all they could imagine themselves holding in the future. We uncovered gender gaps in receptivity toward the three political positions about which we asked, as well as a series of other careers that can be classified as either historically male or historically female. For all three public offices-president, member of Congress, and mayor-men were at least one-third more likely than women to be open to the position. Men were also more likely than women to be attracted to a career in business and science, whereas women were more likely than men to express interest in being a teacher, nurse, or secretary. In fact, nearly twice as many female respondents were open to being a secretary as were open to serving in Congress.

These gender gaps in political ambition are striking not only because female and male respondents were similarly situated demographically, but also because they were equally likely to have participated in political activities. From voting, to attending a protest or rally, to blogging or emailing about a cause, to posting about or following a politician on a social networking site, we uncovered comparable rates of activism. They also held similar attitudes about politics and politicians; female respondents were no more likely than male respondents to hold politicians in low regard, for example.

Thus, if attitudes toward politicians and levels of political activity situate young people to think about running for office, then female respondents are as wellpositioned as their male counterparts. Yet these data make clear that young women and men are not equally 


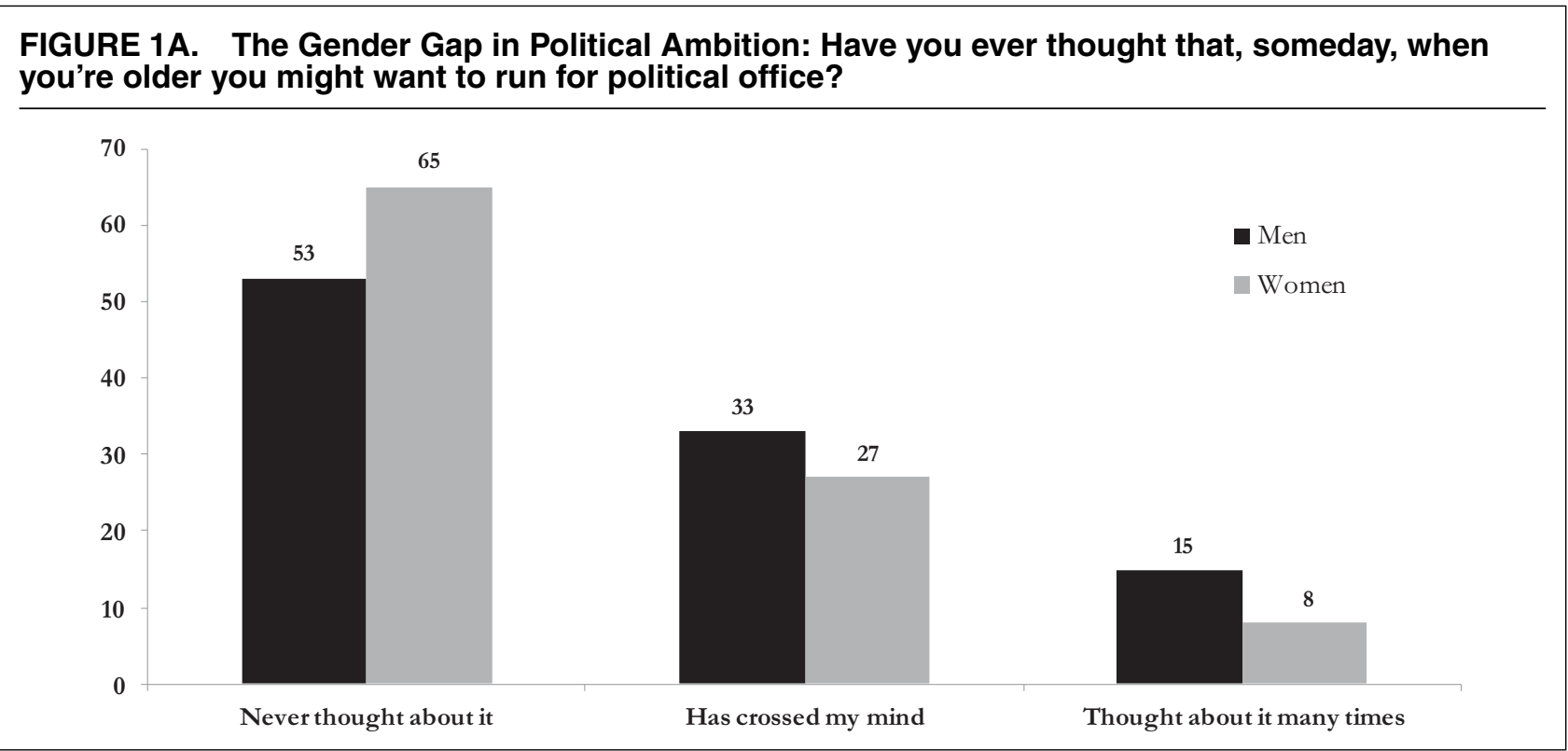

FIGURE 1B. Interest in Running for Office in the Future: Even if you've never thought about it, how likely would you be to run for political office at some point in the future?

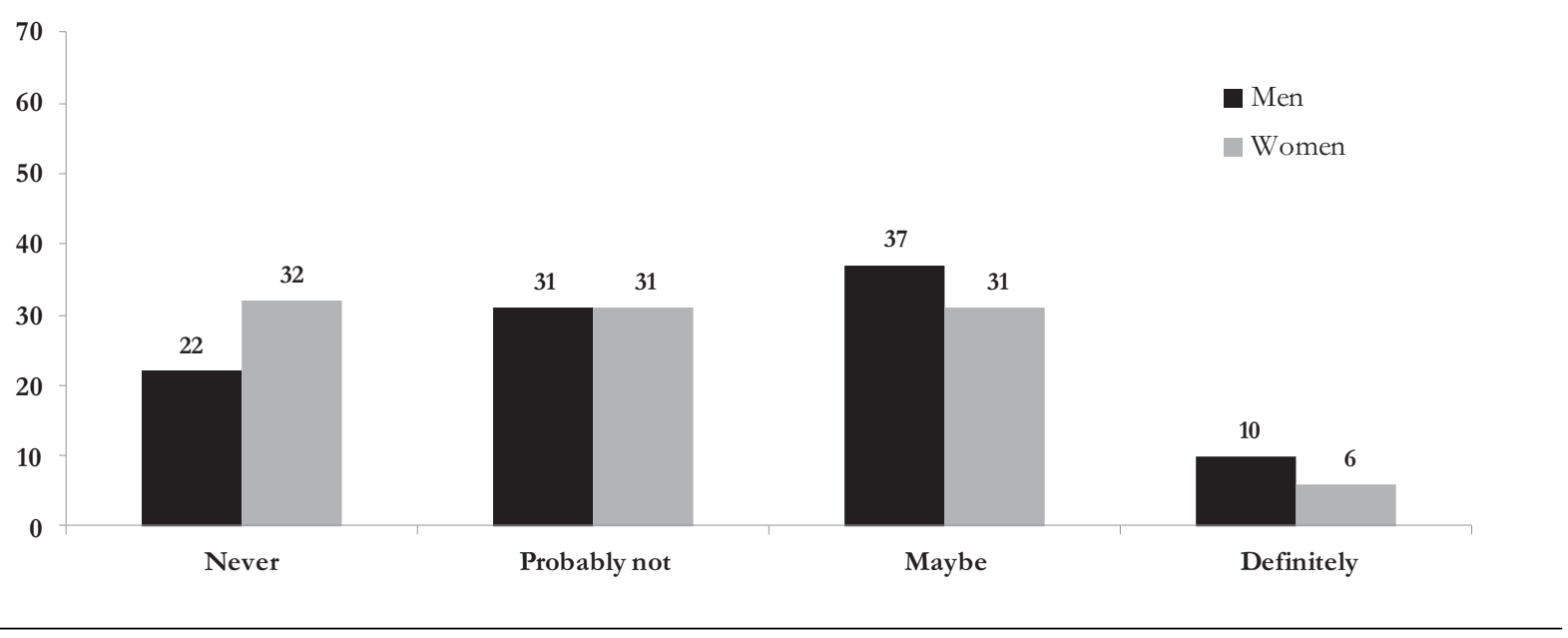

Notes: Data are based on responses from 1,923 men and 2,011 women, all of whom are either in college or plan to attend college. Bars represent the percentage of men and women who fall into each category. In all comparisons except "probably not," the gender gap is statistically significant at $p<.05$.

likely to consider running for office a desirable future endeavor. Our findings establish a consistent and considerable gender gap in political ambition that predates women and men's entry into the professions that tend to lead to political careers.

\section{THE GENDER GAP IN POLITICAL AMBITION AMONG YOUNG CITIZENS: THEORY AND LITERATURE}

Where does the gender gap in political ambition originate? Political socialization - which we define to include experiences that either directly or indirectly shape political attitudes and behavior in childhood and early adulthood-offers a compelling theoretical framework through which to understand the genesis of the gender gap in political ambition among young citizens. We argue that the multifaceted lens through which individuals come to see the world politically affects not only the propensity to express interest in running for office, but also accounts for gender differences therein. We draw on scholarship and empirical evidence from literatures on candidate emergence, political socialization, and political participation to derive five expectations to explain the origins of the gender gap in political ambition and the specific early life experiences that contribute to and sustain it.

Family Socialization. Family experiences early in life have lasting power to shape adults' political 


\section{FIGURE 2A. A Mayoral Career: If the following jobs paid the same amount of money, which would you most like to be?}

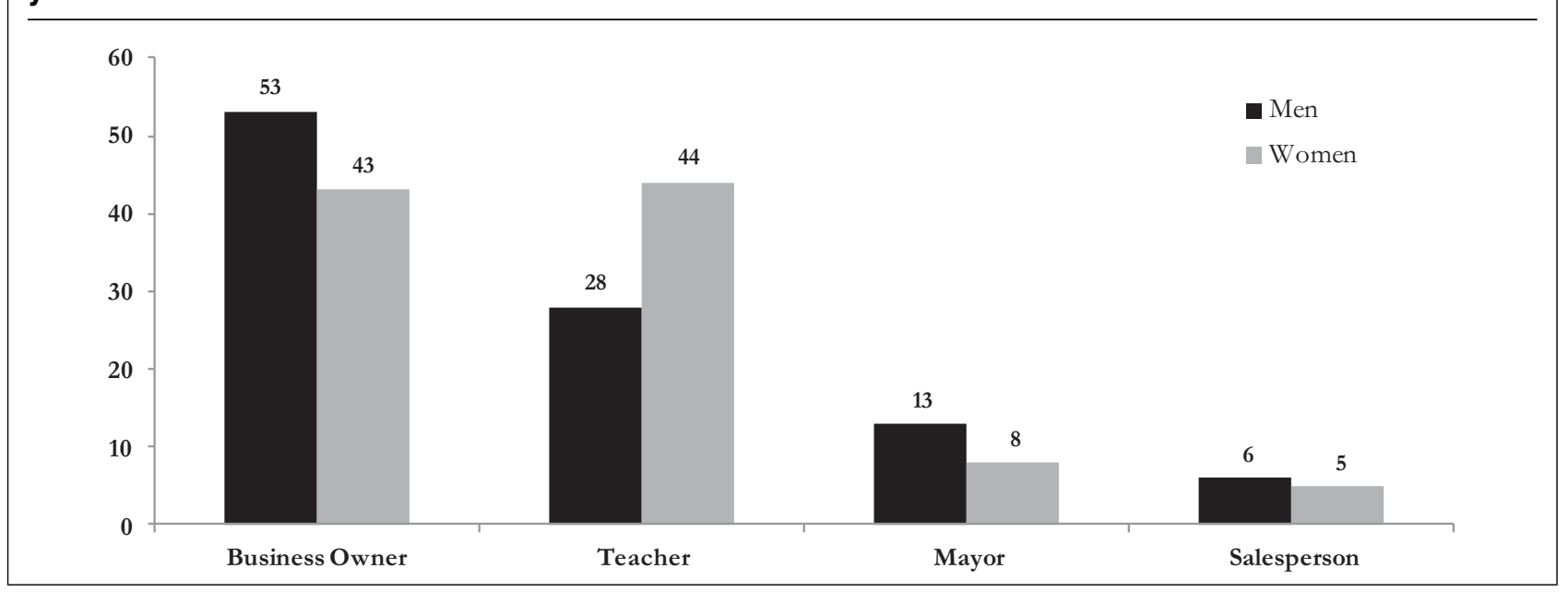

\section{FIGURE 2B. A Congressional Career: If the following jobs paid the same amount of money, which would you most like to be?}

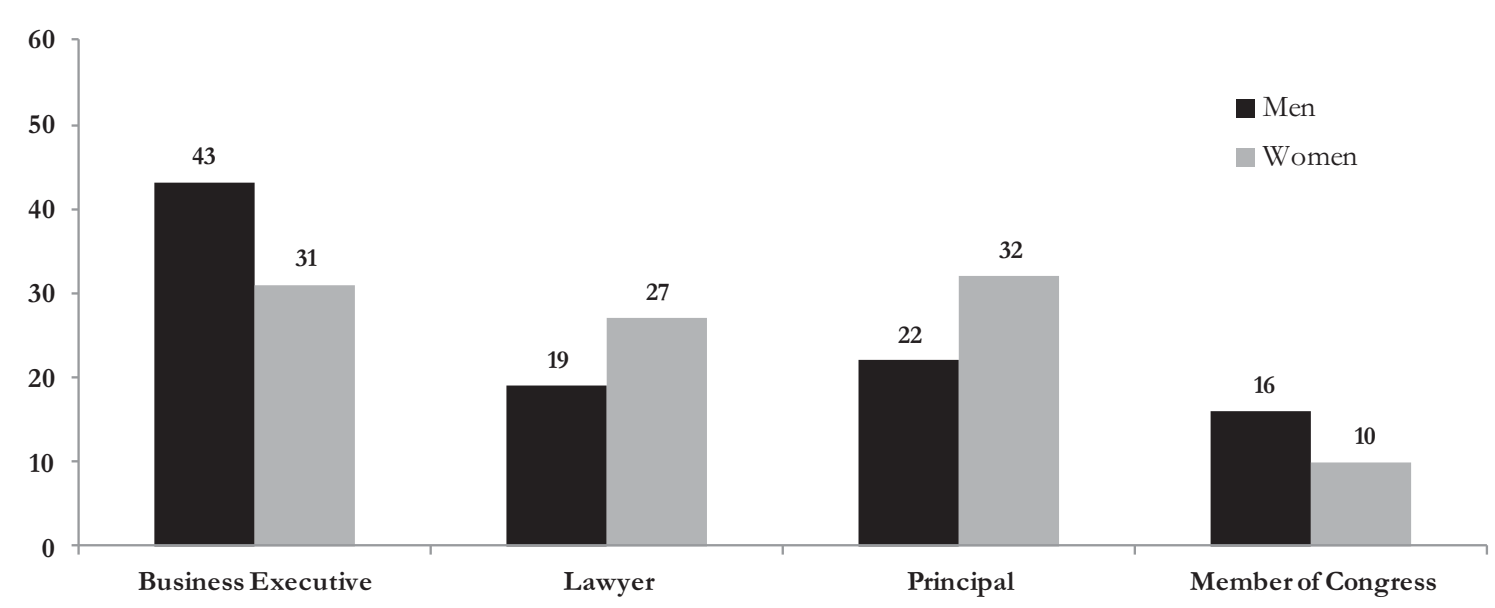

Notes: Data are based on responses from 1,907 men and 1,998 women, all of whom are either in college or plan to attend college. Bars represent the percentage of men and women who ranked each position as their most desirable when presented with the list of four options. In all comparisons except salesperson, the gender gap is statistically significant at $p<.05$.

attitudes and behavior. Political party affiliation, for instance, is often handed down from parent to child (Jennings, Stoker, and Bowers 2009; Fiorina 1981). Notions of good citizenship and political activism and interest can also be traced back to political passion and activity in the childhood home (Jennings and Markus 1984; Jennings and Stoker 2012; Verba, Schlozman, and Burns 2005). And recent studies suggest that adolescents who discuss politics with their parents develop higher levels of political knowledge and demonstrate a greater propensity to vote, attend community meetings, and engage the political system through signing petitions, participating in boycotts, or contributing money (Andolina et al. 2003; Jennings 2002; McIntosh, Hart, and Youniss 2007). It follows, therefore, that high school and college students who live(d) in politicized homes might be more interested in running for office later in life than those who live(d) in less politicized family environments. $^{5}$

Certainly, socialization in the family unit can shape both young men and women's political interest and ambition. But women may be less likely than men to experience a politicized upbringing. A survey of lawyers, business leaders, educators, and political activists found that women were nearly $20 \%$ less likely than men to remember speaking about politics with their fathers; and they were $15 \%$ less likely than men to report that their parents had encouraged them to run for office

\footnotetext{
${ }^{5}$ Scholars have also begun to explore the extent to which political attitudes and behaviors are the result not only of environmental and socialized factors, but also genetic factors passed on from one generation to the next (see, for example, Alford, Funk, and Hibbing 2005; Charney and English 2012; Fowler and Dawes 2008).
} 
(Lawless and Fox 2010, 66). Perhaps as a result of these family experiences, $15 \%$ of men, compared to only $9 \%$ of women, reported that they first considered running for office before they graduated from high school (difference significant at $p<.05$ ). Although these findings succumb to the aforementioned methodological limitations involved in relying on adults' retrospective accounts of their childhoods, they reflect patterns of socialization that promote men's greater suitability to enter the political sphere.

Political Context. Beyond the primary socializing agent of family, other contextual factors also affect young people's political behavior. Indeed, similar to the manner in which social networks influence adults' political behavior and attitudes (Ahn, Huckfeldt, and Ryan 2010; Huckfeldt and Mendez 2008; Ryan 2011), school experiences, peer associations, and media habits can affect young citizens' political attitudes. In terms of educational experiences, politicized classroom programs in high schools can increase students' intentions to vote (Billig, Root, and Jesse 2005; see also Campbell 2008) and their sense of political efficacy (Pasek et al. 2008). College students majoring in social sciences that facilitate the development of civic skills are also more likely to participate politically (Hillygus 2005). Outside the classroom, adolescent participation and leadership roles in extracurricular activities, community clubs, and organizations increase the propensity to participate civically and politically as an adult (Glanville 1999; Hart et al. 2007; Kirlin 2003). Volunteering for politicized clubs and groups, as well as associating with the people in such groups, are also strongly linked to political interest later in life (McFarland and Thomas 2006). Finally, media - particularly internet and webbased technologies - can teach civic skills, bolster future civic engagement and efficacy, and increase youth political interest and voter turnout (Iyengar and Jackman 2004; Montgomery, Gottlieb-Robles, and Larson 2004). Thus, we expect young women and men who navigate politicized environments at school, with their friends, and through the media to be more politically ambitious than those with educational and peer contexts that are less politically charged.

Like family, these contextual factors should affect both young women and men's ambition. But gender differences in exposure to these agents of political socialization might result in an advantage for men. Historically, male college students have been more likely than their female counterparts to major in political science and government (APSA 2010). These gender differences are relevant because exposure to, and the influence of, faculty and peers in college can affect political beliefs (Dey 1996). Similarly, research regarding internet habits reveals that young men spend more time than young women reading news and absorbing political information (Fuller 2004). Coupled with gender segregation in many social networks (McClurg, Wade, and Wright-Phillips 2013), the educational, peer, and media contexts in which young women and men operate may provide men with more exposure to experiences that spur interest in running for office.
Competitive Experiences. There is broad acceptance of the notion that anyone who ultimately decides to seek high-level office is competitive and driven. High school and college students' experiences with competition-from student government elections to mock trial and debate competitions to leadership activities to sports - may foster the competitive drive that facilitates openness to entering the electoral arena in the future. A growing body of research finds, for example, that athletic participation carries longstanding positive economic and psychological benefits. Former high school athletes receive higher wages and better benefits later in life than do their nonathlete counterparts (Ewing 2007; see also Barron et al. 2000; Stevenson 2010). Athletic participation also often enhances discipline, confidence, self-esteem, motivation, and a competitive spirit (Erkut et al. 1996; Lechner 2009), all of which are relevant for political success. ${ }^{6}$ Student government elections operate similarly; participating in a campaign, even in high school or college, can demystify the political process and prepare young adults to embrace competition (see Lawless and Fox 2010). Hence, we expect a positive relationship between indicators of competitive behavior early in life and an openness toward running for office later in life.

Although women and men can benefit from the competitive environments provided by athletics and competitive experiences at school, female high school and college students may be less likely than men to take advantage of them. When comparing professional performance in competitive and noncompetitive environments among adults, investigators find that men are more likely than women to seek out competitive environments and to exude confidence when competing (Gneezy, Niederle, and Rustichini 2003; Niederle and Vesterlund 2007). Moreover, although public support for gender equality in athletic opportunities is high (Sigelman and Wilcox 2001) and women's participation has substantially increased, Title IX has not eliminated unequal access to sports. ${ }^{7}$ Young women, therefore, may be at an overall disadvantage in terms of the socialized benefits they can accrue from these activities.

Self-Confidence. The extent to which individuals are confident about and perceive that they possess politically relevant skills and traits shapes their assessments

\footnotetext{
${ }^{6}$ We recognize that most research finds that playing sports does not influence political engagement in adults or young people (Kahne and Sporte 2008; Verba, Schlozman, and Brady 1995). But scholars do find that athletics can encourage civic engagement when they consider sports as part of a long list of voluntary activities (Marks and Jones 2004; Smith 1999; Walker 2008), though the direct link is tenuous. For our purposes, we consider athletic participation a potentially relevant predictor of political ambition not because of its relationship to civic engagement, but rather, because it is a competitive activity that might correlate with interest in competing in the political arena. Thus, we gauge the extent to which young people are competitive while playing sports, not merely whether they do so.

${ }^{7}$ Data from 2011 to 2012 reveal that men comprise roughly $57 \%$ of NCAA athletes, a proportion that has held steady for the last decade (Brown 2012). Data from 2008 to 2009 show that $55 \%$ of students participated in high school athletics, but the gender gap was sizeable; 3.1 million high school athletes were female, compared to 4.4 million who were male (Howard and Gillis 2009).
} 
of whether they are qualified to run for office (Fox and Lawless 2011). Evidence suggests, however, that whereas men are socialized to be confident, assertive, and self-promoting, cultural attitudes toward women as political leaders continue to leave an imprint suggesting to women - if even only subtly - that it is often inappropriate or undesirable to possess these characteristics (Enloe 2004; Flammang 1997). In fact, men and women perceive women to be less knowledgeable than men about politics, regardless of their actual levels of political knowledge (Mendez and Osborn 2010). Women's tendency to diminish and undervalue their professional skills and achievements is in place by the time of adolescence. Male and female students in mathematics and language arts, for example, have vastly different perceptions of their own skills; male students overestimate their skills and female students underestimate theirs relative to objective indicators of competence (Pajares 2002; Wigfield, Eccles, and Pintrich 1996).

Gender differences also exist in the confidence women and men exhibit regarding their credentials and backgrounds. Social psychologists find that, in general, men are more likely than women to express confidence in skills they do not possess and overconfidence in skills they do (Kling et al. 1999). Men tend to overestimate their intelligence, while women tend to underestimate theirs (Beloff 1992; Furnham and Rawles 1995). And men often fail to incorporate criticism into their selfevaluations, whereas women tend to be strongly influenced by negative appraisals of their capabilities (Roberts 1991). Although high school and college students may not have fully formed opinions about their qualifications to run for office, the literature suggests that men will be more likely than women to express the confidence that, someday, they will be qualified.

Gender Roles and Identity. Traditional family dynamics and role orientations - in which women are the primary caretakers of the family and exist in the private domain, but men are the primary breadwinners and occupy public roles - persist in a substantial number of households (Marks, Bun, and McHale 2009). When women do enter the workforce, analyses of the labor market confirm occupational gender segregation with the persistent grouping of "women's" and "men's" careers (Hegewisch et al. 2010). Holding political office has always been considered a "men's" career, so we expect that young women who have been socialized to hold attitudes that embody traditional gender roles and orientations may be less likely to exhibit political ambition than those with more egalitarian views about family dynamics and career options.

Whereas traditional gender role orientations might stunt young women's political ambition, exposure to female role models might promote it. Female role models from high schools to doctoral programs, for example, can help facilitate women's success (Marx and Roman 2002; Nixon and Robinson 1999). In terms of politics, Atkeson (2003) finds that women who live in states with successful, visible female candidates are more likely to be politically engaged. Women's levels of political pros- elytizing (Hansen 1997) and political interest (Burns, Schlozman, and Verba 2001) also correlate with the presence of female elected officials. More directly, a cross-national examination found that the presence of female political leaders increased adolescent girls' likelihood of planning to be politically active (Campbell and Wolbrecht 2006). Thus, we expect that young women who rely on female role models for career advice will be more likely than those who don't to express interest in running for office in the future. ${ }^{8}$

Undoubtedly, these five research expectations are interrelated, and there are likely some complex causal relationships among them, as is often the case with political socialization research. Further, ours is a temporal argument that assumes that these central expectations predate the development of political ambition. This is not to say that respondents who are politically ambitious might not initiate more politicized family activities or seek out a more politicized context in their personal surroundings. But it is difficult to conceptualize how political ambition could develop without-let alone cause-experiences such as having political discussions in the household, engaging in competitive activities, or possessing a broad sense of self-confidence. Together, therefore, these explanations represent a series of early life experiences and socialized attitudes and behaviors that may influence political ambition. The gendered component of each suggests that they will also account for the bivariate level gender gap we uncovered in young people's interest in running for office.

\section{EXPLAINING THE GENDER GAP IN POLITICAL AMBITION AMONG YOUNG CITIZENS: DATA AND ANALYSIS}

To examine why some young women and men express interest in running for office in the future, while others do not, as well as to delve into the roots of the gender gap in political ambition, we developed eight regression equations. Table 1 reports ordered logistic regression coefficients for four equations that predict interest in running for office using a four-point scale. Respondents could have scored between a 1 ("absolutely no interest in a future candidacy") and a 4 ("definitely plan to run in the future"). Although our expectations apply to both high school and college students, college students may be more likely to consider a candidacy; as people get older and accumulate more diverse experiences, they are more cognizant of opportunities they had not previously considered. Thus, the first two columns of Table 1 present models based on the pooled sample of high school and college students, but include

\footnotetext{
${ }^{8}$ This expectation focuses only on female respondents. Certainly, young men's exposure to traditional versus egalitarian family and career dynamics in their childhood homes varies, as do their attitudes toward women's capabilities to work in traditionally "male" domains. But Tolleson-Rinehart $(1992,33)$ convincingly argues against the merits of "male gender consciousness," explaining that men tend not to assess their societal, economic, and political status relative to other groups. Rather, the status of the white male tends to be the yardstick against which other groups evaluate their own fortunes.
} 


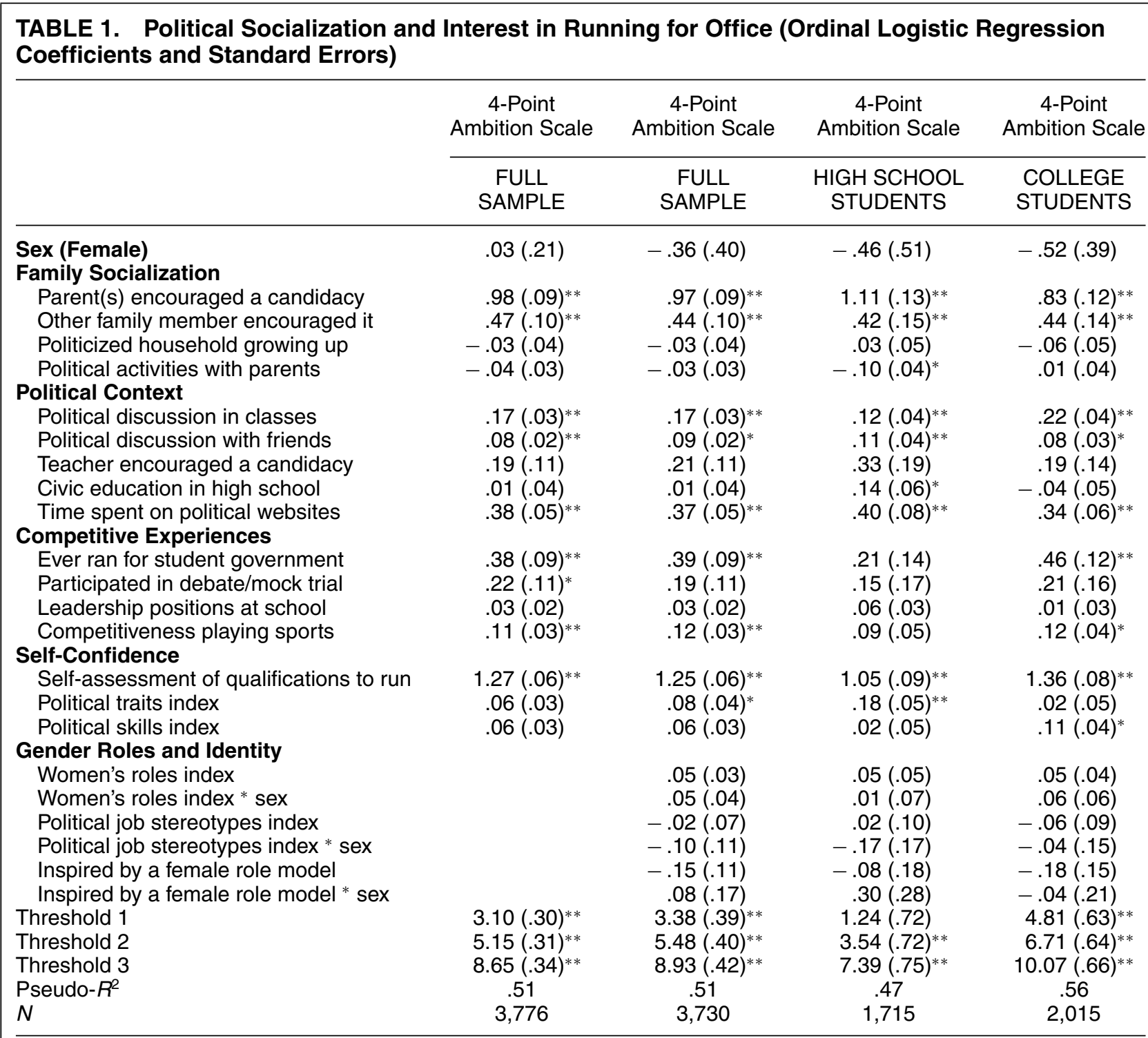

Notes: Models include controls for Black, Latino, Democrat, Republican, income, age, and political participation. Full Sample models also include controls for whether the respondent is in high school or college, and an interaction between subsample and respondent sex. Levels of significance: ${ }^{* *} p<.01 ;{ }^{*} p<.05$.

an indicator variable for whether the respondent is in high school or college, as well as an interaction between sex and subsample. The third and fourth columns restrict the analysis by subsample, which allows us to examine with more nuance whether the same factors affect political ambition among high school and college students, as well as whether their relative substantive effects vary across subsample.

The models operationalize the research expectations we identified with a series of original measures that tap into high school and college students' experiences (see Appendix B for a description of the variable coding). Because we expect gender roles and identity to affect only female respondents' interest in running for office, we interact the three gauges we use to measure this expectation with respondent sex. And to ensure that our results are not an artifact of the multiple interaction terms, we also perform the analyses without the gender roles and identity variables (see column 1). Each equation includes a series of demographic and political controls: race, age, region, household income, party identification, and political activity.

Because the majority of respondents are neither certain that they will run for office nor have dismissed the possibility outright, we also perform our analysis with a collapsed version of the four-point scale. Table 2 presents four logistic regression equations that predict political ambition with a dichotomous dependent variable that indicates whether the respondent is at least open to the idea of running for office in the future. As is the case with Table 1, we perform the analysis first on the full sample and then restrict the analysis to the high school and college subsamples. 
TABLE 2. Political Socialization and Interest in Running for Office (Binary Logistic Regression Coefficients and Standard Errors)

\begin{tabular}{|c|c|c|c|c|}
\hline & $\begin{array}{l}\text { At Least Open } \\
\text { to Running }\end{array}$ & $\begin{array}{l}\text { At Least Open } \\
\text { to Running }\end{array}$ & $\begin{array}{l}\text { At Least Open } \\
\text { to Running }\end{array}$ & $\begin{array}{l}\text { At Least Open } \\
\text { to Running }\end{array}$ \\
\hline & $\begin{array}{l}\text { FULL } \\
\text { SAMPLE }\end{array}$ & $\begin{array}{l}\text { FULL } \\
\text { SAMPLE }\end{array}$ & $\begin{array}{l}\text { HIGH SCHOOL } \\
\text { STUDENTS }\end{array}$ & $\begin{array}{l}\text { COLLEGE } \\
\text { STUDENTS }\end{array}$ \\
\hline Sex (Female) & $.02(.28)$ & $-.01(.54)$ & $.10(.68)$ & $-.42(.53)$ \\
\hline \multicolumn{5}{|l|}{ Family Socialization } \\
\hline Parent(s) encouraged a candidacy & $1.17(.10)^{* *}$ & $1.18(.10)^{* *}$ & $1.25(.14)^{* *}$ & $1.05(.15)^{* *}$ \\
\hline Other family member encouraged it & $.66(.13)^{* *}$ & $.65(.13)^{* *}$ & $.50(.19)^{* *}$ & $.79(.18)^{* *}$ \\
\hline Politicized household growing up & $-.04(.05)$ & $-.03(.05)$ & $-.04(.07)$ & $-.00(.07)$ \\
\hline Political activities with parents & $-.02(.04)$ & $-.02(.04)$ & $-.07(.06)$ & $.01(.05)$ \\
\hline \multicolumn{5}{|l|}{ Political Context } \\
\hline Political discussion in classes & $.15(.03)^{* *}$ & $.15(.03)^{* *}$ & $.09(.05)$ & $.23(.05)^{* *}$ \\
\hline Political discussion with friends & $.07(.03)^{*}$ & $.07(.03)^{*}$ & $.11(.05)^{*}$ & $.03(.05)$ \\
\hline Teacher encouraged a candidacy & $.22(.15)$ & $.23(.15)$ & $.54(.25)^{*}$ & $.08(.20)$ \\
\hline Civic education in high school & $-.01(.05)$ & $.00(.05)$ & $.16(.08)^{*}$ & $-.09(.07)$ \\
\hline Time spent on political websites & $.38(.06)^{* *}$ & $.38(.06)^{* *}$ & $.46(.10)^{* *}$ & $.32(.08)^{* *}$ \\
\hline \multicolumn{5}{|l|}{ Competitive Experiences } \\
\hline Ever ran for student government & $.28(.11)^{* *}$ & $.28(.11)^{*}$ & $.10(.17)$ & $.41(.16)^{* *}$ \\
\hline Participated in debate/mock trial & $.43(.15)^{* *}$ & $.41(.15)^{* *}$ & $.51(.22)^{*}$ & $.33(.22)$ \\
\hline Leadership positions at school & $.01(.03)$ & $.01(.03)$ & $.02(.04)$ & $.00(.04)$ \\
\hline Competitiveness playing sports & $.05(.04)$ & $.05(.04)$ & $.03(.06)$ & $.06(.06)$ \\
\hline \multicolumn{5}{|l|}{ Self-Confidence } \\
\hline Self-assessment of qualifications to run & $1.19(.08)^{* *}$ & $1.18(.08)^{* *}$ & $.94(.11)^{* *}$ & $1.36(.10)^{* *}$ \\
\hline Political traits index & $.14(.05)^{* *}$ & $.15(.05)^{* *}$ & $.19(.07)^{* *}$ & $.14(.06)^{*}$ \\
\hline Political skills index & $.09(.04)^{*}$ & $.09(.04)^{*}$ & $.07(.06)$ & $.12(.06)$ \\
\hline \multicolumn{5}{|l|}{ Gender Roles and Identity } \\
\hline Women's roles index & & $.02(.04)$ & $.05(.07)$ & $-.00(.06)$ \\
\hline Women's roles index * sex & & $-.00(.06)$ & $-.10(.09)$ & $.06(.08)$ \\
\hline Political job stereotypes index & & $.08(.09)$ & $.09(.13)$ & $.08(.12)$ \\
\hline Political job stereotypes index * sex & & $-.07(.15)$ & $-.02(.22)$ & $-.09(.20)$ \\
\hline Inspired by a female role model & & $-.23(.15)$ & $-.12(.24)$ & $-.27(.20)$ \\
\hline Inspired by a female role model * sex & & $.14(.22)$ & $.50(.39)$ & $-.06(.29)$ \\
\hline Constant & $-5.02(.41)^{* *}$ & $-5.04(.52)^{* *}$ & $-2.51(.94)^{* *}$ & $-6.76(.88)^{* *}$ \\
\hline Percent Correctly Predicted & 79.3 & 79.3 & 78.1 & 80.1 \\
\hline Pseudo- $R^{2}$ & .51 & .51 & .47 & .55 \\
\hline$N$ & 3,776 & 3,730 & 1,715 & 2,015 \\
\hline
\end{tabular}

Most of the results that emerge from the regression analyses are consistent with our expectations. ${ }^{9}$ Three broad findings merit discussion because they allow us to gain leverage over the factors that contribute to young citizens' political ambition, as well as speak to the origins of the gender gap in interest in running for office in the future.

\section{Identifying the Origins of Political Ambition}

Our results demonstrate that political socialization provides a useful framework through which to analyze

\footnotetext{
${ }^{9}$ The results are similar when we perform the analysis separately by respondent age, as well as when we group respondents by age cohort (13 and 14 year olds, 15 and 16 year olds, etc.). The gender gap in political ambition within the high school and college subsamples also remains relatively constant across ages, and when deviations do occur, they are not systematic or linear (see Appendix C).
}

young people's political ambition and openness toward a future candidacy. Overall, regardless of whether we code ambition using the four-point scale or a dichotomous variable, family socialization, political context, competitive experiences, and self-confidence affect interest in running for office in the future. ${ }^{10}$ And the same general explanations confer explanatory power even when we restrict the analyses to the high school and college subsamples. The Gender Roles and Identity expectation is the only one for which we do not uncover

\footnotetext{
${ }^{10}$ Most of the control variables work in the expected ways, too. Level of political activity is positive and significant, and household income is negative and significant. Latino respondents are slightly more likely than White respondents to articulate interest in running for office in the future. In none of these cases, however, do we uncover notable gender differences. Respondents' party identification and region are not statistically significant, either alone, or when interacted with sex.
} 

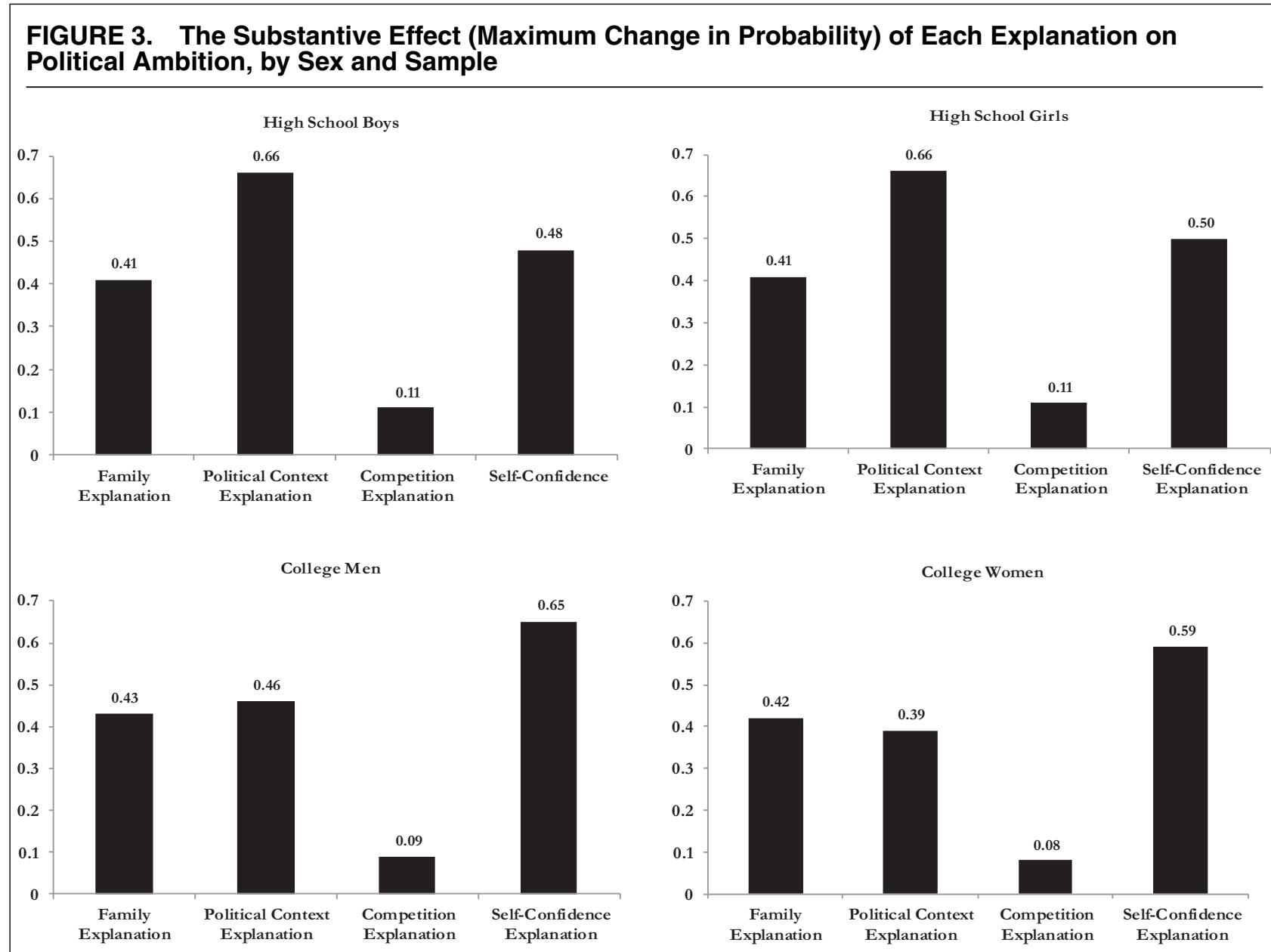

Notes: Changes in probabilities are based on the logistic regression results presented in Table 2, columns 3 and 4 . These probabilities were calculated by setting all continuous independent variables to their means and dummy variables to their modes for the three expectations not under consideration. Within each individual expectation, we assessed the maximum change in probability for each statistically significant variable (i.e., the family explanation probability reflects the fact that a respondent who was encouraged to run for office by a parent and another family member was 41-43 percentage points more likely (depending on sex and subsample) than a respondent who received no such encouragement, all else equal, to be open to running for office in the future).

support. ${ }^{11}$ Figure 3 presents the maximum change in probability conferred by each of the four significant expectations (based on the logistic regression results presented in Table 2, columns 3 and 4$){ }^{12}$

\footnotetext{
${ }^{11}$ Although delving deeply into this null finding is beyond the scope of this article, the lack of explanatory power conferred by the Gender Roles and Identity explanation could be a result of various factors. Because the female role models in the respondents' lives are not, necessarily, women in public life, there may be no reason to expect them to be a source of political inspiration. In fact, some research even finds that women represented by women in politics are no more likely to engage the political system than women who are not (see Dolan 2006; Lawless 2004), and in these cases, the role models are unquestionably political. It is also possible that the null findings are an artifact of limited variation on the Gender Roles and Identity variables. Eighty percent of respondents reported at least one female role model.

12 There are some minor differences in which variables achieve statistical significance when we rely on the four-point scale versus the dichotomous indicator of political ambition. The only substantively meaningful difference, however, pertains to the power of the Competitive Experiences expectation for high school students. Partici-
}

We calculated these probabilities by setting all continuous independent variables to their subsample means and dummy variables to their subsample modes for the three expectations not under consideration. Within each individual expectation, we assessed the maximum change in probability for all statistically significant variables. The Family Explanation probability, for example, is presented as the first bar in each quadrant of Figure 3. The bars reflect the fact that a respondent who was encouraged to run for office by at least one parent and one other family member is between 41 and 43 percentage points more likely than a respondent who received no such encouragement, all

pating in mock trial and/or debate is significant when we predict ambition using a dichotomous variable, but not when we rely on the ordinal measure. To err on the side of caution and ensure that we do not attribute substantive findings to possible measurement error, we focus the bulk of our analysis - at least pertaining to the high school subsample - on the other three explanations. 
else equal, to be open to the idea of running for office later in life. ${ }^{13}$

In addition to family, several other primary agents of political socialization correlate positively with interest in running for office in the future. Navigating a more politicized environment generates a similarly powerful impact. Consider the effect of media habits. On average, a college respondent who visits political websites every day is almost twice as likely as one who rarely or never consults such sites to be interested in running for office (0.46 compared to 0.25 predicted probability); high school students receive a nearly 30 percentage point boost. Further, high school respondents who frequently discuss politics with their friends are 13 percentage points more likely than those who do not to express ambition to run for office.

Beyond these classic agents of socialization, the regression results make clear that experiences with competition, as well as an overall sense of confidence in one's own abilities, are associated with heightened levels of political ambition. Running for student government, for instance, confers the same substantive effect for college students as does participating in mock trial or the debate team for high school students. In each case, the competitive experience raises a respondent's likelihood of being open to the idea of running for office by 10 percentage points. A sense of confidence exerts the largest relative effect on political ambition for the college subsample and the second largest effect for the high school subsample. More specifically, college-age respondents who contend that, at some point in the future, they will know enough to run for office are approximately 58 percentage points more likely than those who doubt their future knowledge to express interest in a candidacy. High school students receive a roughly 40 percentage point boost.

Whereas the importance of Family Socialization and Competitive Experiences tend to affect high school and college students' ambition comparably, the data presented in Figure 3 demonstrate that Political Context is the most important explanation for high school students' interest in running for office, but SelfConfidence is the largest relative predictor for college students. Across the board, however, young people's political ambition is related to and shaped by a variety of experiences, traits, and activities early in life. Our evidence suggests - not based on retrospective assessments, but rather, in real time-that these circumstances leave an important imprint, as they affect the educational, professional, and political decisions women and men will make later in life.

\section{Accounting for the Gender Gap in Ambition}

The socializing effects of early life experiences are important not only because they help us understand what types of young people are interested in running for office, but also because they account for the gender gap in high school and college students' political ambition that we uncovered at the bivariate level. In no equation does the sex of the respondent achieve statistical significance. ${ }^{14}$ And the same variables are significant when we analyze the subsamples of women and men separately (results not shown).

The statistically insignificant coefficients on sex, however, must be interpreted in light of the significant gender differences in the variables that affect political ambition. Once we account for gender differences in these factors, male and female respondents are not equally likely to express interest in running for office. More specifically, when we generate a baseline predicted probability for the "average" high school boy (based on the regression equation presented in Table 2, column 2), the typical respondent has a 0.23 predicted probability of being open to running for office later in life. ${ }^{15}$ We calculated the probability by setting all explanatory and control variables to the means and modes for the male high school subsample. High school girls, on average, have a 0.20 predicted probability of expressing interest in running for office in the future. The small gender gap between high school boys and girls, therefore, is an artifact of male and female respondents not being similarly situated on key factors associated with political ambition.

Gender differences are more striking when we turn to the college students in the sample. Again, even though the coefficient on sex is statistically insignificant, embedded within the probabilities are gender differences in respondents' family socialization, political environments, competitive experiences, and selfconfidence. Setting these values to their subsample means and modes results in an average female college student with a 0.19 predicted probability of being open to running for office in the future. College men have an average predicted probability of 0.33 , which means that they are approximately $74 \%$ more likely than college women to express political ambition (we analyze and discuss these differences in the next section).

Young women and men arrive at their ambition similarly, and they rely on the same factors when considering a future in politics. But women are not as likely as men to possess the ingredients associated with interest in running for office.

\footnotetext{
${ }^{13}$ Because the other two variables included in the Family Explanation are not statistically significant, the maximum changes in probability do not include varying those measures from their minimum to maximum values. Differences in substantive effects of the four explanations across subsamples are not statistically significant. And although we rely on the separate equations for high school and college students to generate these probabilities, the results are not notably different when we generate probabilities from the pooled equation (Table 2, column 2); see Appendix D.
}

\footnotetext{
${ }^{14}$ Important for our purposes, sex is statistically significant in a model that includes only the demographic and political controls. Only by supplementing that model with our measures that tap into the various facets of political socialization do we account for gender differences in political ambition.

${ }^{15}$ We generate these predicted probabilities based on the pooled sample so that we can make direct comparisons across the four subsamples of respondents. The predicted probabilities, however, are very similar when we generate them from the separate regression equations for the high school and college subsamples.
} 


\begin{tabular}{|c|c|c|c|c|}
\hline & $\begin{array}{l}\text { High School } \\
\text { Boys }\end{array}$ & $\begin{array}{l}\text { High School } \\
\text { Girls }\end{array}$ & $\begin{array}{l}\text { College } \\
\text { Men }\end{array}$ & $\begin{array}{l}\text { College } \\
\text { Women }\end{array}$ \\
\hline \multicolumn{5}{|l|}{ Family Socialization Explanation } \\
\hline At least one parent suggested running & $34 \%$ & $32 \%$ & $36 \% * *$ & $26 \%$ \\
\hline Another family member suggested running & 18 & 16 & $23^{* *}$ & 16 \\
\hline \multicolumn{5}{|l|}{ Political Context Explanation } \\
\hline Discusses politics at school at least weekly & 39 & 37 & $35^{*}$ & 30 \\
\hline Discusses politics with friends at least weekly & 13 & 10 & $27^{* *}$ & 20 \\
\hline Visits political websites rarely or never & $62^{*}$ & 69 & $28^{* *}$ & 40 \\
\hline Visits political websites every day & 5 & 5 & $17^{*}$ & 9 \\
\hline At least some civic education & 55 & 60 & - & - \\
\hline \multicolumn{5}{|l|}{ Competitive Experiences Explanation } \\
\hline Ran for student government & - & - & 26 & 25 \\
\hline Never played a sport & - & - & $14^{* *}$ & 29 \\
\hline "Very competitive" when playing sports & - & - & $38^{* *}$ & 23 \\
\hline \multicolumn{5}{|l|}{ Self-Confidence Explanation } \\
\hline Will not be qualified to run for office in future & 29 & 34 & $31^{* *}$ & 51 \\
\hline Will be qualified to run for office in future & 14 & 15 & $23^{* *}$ & 11 \\
\hline$N$ & 903 & 915 & 1,020 & 1,097 \\
\hline
\end{tabular}

\section{Identifying When the Gender Gap in Political Ambition Materializes}

Our analysis allows us to assert with some degree of specificity when the gender gap in ambition fully materializes. The baseline probabilities described above highlight that gender differences in interest in running for office are more substantial among college than high school students. The data presented in Table 3 shed light on the underlying reasons for this finding; the gender differences in the central factors associated with interest in running for office are more pronounced among college than high school students. ${ }^{16}$

Among high school students, we uncover only one significant gender difference: high school girls are significantly less likely than boys to visit political websites. While we do not want to minimize this difference, it is important to assess it relative to those we find among the college sample. On 10 of the 11 indicators displayed in Table 3, college women are significantly less likely than college men to benefit from the socializing forces, experiences, and characteristics that spur and reinforce political ambition. Compared to women, men in college are roughly one-third more likely to receive encouragement from their parents to run for office, discuss politics regularly with their friends, and consider themselves very competitive. They are almost twice as likely as college women to visit political websites on a regular basis. And more than twice as many men as women are

\footnotetext{
${ }^{16}$ The comparisons in Table 3 are taken from several of the questions used in the regression analyses from Table 2. In most cases, we present the percentages of women and men who fell at each end of the continuum of the variable in question.
}

confident that they will be qualified to run for office in the future.

When a college woman possesses the ingredients that contribute to political ambition, however, she is just as likely as her male counterpart to articulate interest in running for office. Consider a female college student who has received encouragement to run for office from her parents, discusses politics regularly with her friends, is competitive when playing sports, visits political websites often, and believes that she will be qualified to run for office in the future. Our models indicate that such a woman has a 0.89 predicted probability of being open to running for office in the future. A college man with comparable experiences has roughly the same likelihood of being politically ambitious ( 0.92 probability of being open to running for office). ${ }^{17}$ Female college respondents, however, are significantly less likely than men to have these backgrounds.

Without panel data, we are limited in the extent to which we can explain the reason that the gender gap in political ambition is so much larger among college than high school students. We do know, however, that the family circumstances in which both subsamples were raised are comparable, and that the college students report levels of political activity in their homes growing up that match those reported by the respondents still in high school. Thus, the explanation likely lies beyond family socialization and in the personal and academic freedom that college students enjoy compared to their high school counterparts. A majority

\footnotetext{
${ }^{17}$ These probabilities are based on the regression equation presented in Table 2, column 4; the results are generally the same when we perform the calculations based on the equation that pools the high school and college students (Table 2, column 2).
} 
of college students move out of their parents' homes to attend college (Sallie Mae 2012), and even when they don't, their home circumstances often give them more independence. Further, whereas high school curricula generally offer little choice, college provides students with a wide array of academic options and electives. Essentially, when students get to college and "the shackles come off," young women and men have much greater control over how they spend their time and to what interests they devote themselves.

When this happens, women and men's interests diverge. Recent analyses of gender differences in the selection of college majors reveal that women are more likely than men to major in psychology and sociology, whereas men are more likely to major in business, engineering, and science (Dickson 2010). Our data indicate that men are also more likely than women to immerse themselves in a political context-from course work, to extracurricular activities, to discussions with friends, to media habits. Male respondents were $10 \%$ more likely than female respondents to have taken at least one political science or government class, and they were almost twice as likely to join either the College Democrats or College Republicans (gender differences significant at $p<.05$ ). This may be a result of the fact that partisan conflict is more likely to promote learning among young men, but young women are more likely to gain information in environments marked by consensus (Wolak and McDevitt 2011). Further, men navigate toward experiences that foster competition; they were more likely than women to play varsity sports $(38 \%$ of men, compared to $26 \%$ of women), as well as intramural sports ( $37 \%$ of men, versus $15 \%$ of women) in college (gender differences significant at $p<.05$ ). These differences can then fuel men's greater confidence to participate in electoral politics at some point in the future. Given that female respondents' political ambition is roughly the same in high school as it is in college, the widening of the gender gap appears to be driven by college men coming to embrace politics and the prospects of entering public life. College provides students the opportunity to select the types of classes and activities with which they feel most comfortablea choice they likely could not make for themselves in high school. Even if many of the seeds of these gender differences are planted in high school, the college atmosphere allows them to flourish.

Beyond having greater autonomy over their interests and activities, college students experience a winnowing of career interests, which coincides with a divergence in women and men's attitudes toward running for office. In an open-ended survey question that asked respondents to identify a specific career interest, twice as many high school students as college students left the question blank. When presented a list of more than 20 jobs to consider as possibilities for the future, college students were roughly $15 \%$ more likely than high school students to express interest in only one job. As they narrow their career interests, occupational gender segregation grows. The gender gap in interest in pursuing a career in historically male fields, like science and law enforcement, for instance, is much larger among college than high school students. Similarly, female college students are more likely than female high school students to indicate that they might become teachers and secretaries. The pattern for political positions is consistent with other historically male professions; college men are $50 \%$ more likely than college women to be interested in serving as mayor, more than twice as likely to be open to serving in Congress, and three times more likely to be willing to serve as president (gender differences significant at $p<.01$ ). No statistically significant differences emerge among high school students' willingness to occupy these political positions.

Importantly, the choices women and men make about what interests and opportunities to pursue occur on college campuses that are still rife with dynamics that can reinforce traditional gender role orientations. Indeed, evidence of the gendered nature of college campuses has emerged in several disciplines. Researchers have found that the transition to university life diminishes women's self-concept more than it does men's; the move from the small pond of high school to the larger pond of college may reduce young women's self-assessments of what they can achieve (Jackson 2003). The prospects of parenthood also play a larger role in college women's self-concepts than men's (Devos et al. 2008). A study of U.S. university students, for instance, found that women and men position themselves differently for careers, parenthood, and marriage, and that these choices account, at least partially, for why women have less prestigious jobs than men upon graduation (Stone and McKee 2000). In addition, academic literatures in education, sociology, and psychology highlight the gendered realities of alcohol consumption, date rape, sexual harassment, and Greek life at American universities, all of which can work to depress women's autonomy (e.g., Armstrong, Hamilton, and Sweeney 2006; Gmelch 1998; Stuber, Klugman, and Daniel 2011). There is little doubt that these dynamics reinforce different roles for women and men in college and play a fundamental role in the "choices" women and men make.

Although we face some data constraints in explaining fully what forces contribute to the differences between high school and college students' political ambition, our results are vitally important because they allow us to pinpoint the phase of life at which gender differences in interest in running for office materialize.

\section{CONCLUSION}

Determining the origins of the gender gap in political ambition is perhaps one of the last critical pieces of the puzzle to understanding gender differences in candidate emergence. This article goes a long way toward shedding light on that puzzle by offering the first in-depth examination of how political socialization, and gendered patterns therein, influence young citizens' ambition to run for office in the future. We uncover powerful effects of early life experiences; the primary agents of political socialization-family, school, 
peers, and media - play an integral part in fostering and reinforcing future interest in running for office. In this regard, ambition to run for office is shaped in much the same way by the forces of political socialization as are political interest, activism, ideology, and party affiliation. But beyond these traditional agents of socialization, participation in competitive activities and a general sense of self-confidence correlate with an openness to running for office.

The combined power of these socializing forces is of the utmost importance because they explain the gender gap in ambition. Women and men rely on the same factors when arriving at their sense of political ambition, but young women are less likely than young men to have these experiences on which to rely. This is especially true among college students, for whom the gender gap in political ambition is at least as large as that among professionals in the candidate eligibility pool. Our findings, therefore, speak to the origins of the gender gap and begin to identify the point in the life cycle when it materializes most fully.

Our results suggest that the gender gap in political ambition, as well as the consequences for women's numeric representation, will likely persist. It is critical to note, however, that this is not because young women have less of a sense of civic duty or different aspirations for the future than do men. In fact, when we asked the respondents about their priorities and life goals, we found few gender differences; young women and men were equally likely to want to get married, have children, earn a lot of money, and achieve career success. Male and female respondents were also equally likely to aspire to improve their communities.

Yet despite their similar life goals, women and men reported very different views when asked about the most effective way to bring about societal change. Thirty-five percent of female respondents, compared to $25 \%$ of male respondents, viewed working for a charity as the best way to bring about change. On the other hand, $26 \%$ of men, but only $17 \%$ of women, saw running for elective office as the best way to ameliorate the society in which they live (gender differences statistically significant at $p<.01)$. Women and men both aspire to work to improve the world around them, but women are less likely than men to see political leadership as a means to that end. Our findings, in essence, highlight the importance of deepening our understanding of the manner in which young women and men in contemporary society are still socialized about politics, from where they receive messages about the acquisition of political power, and the characteristics that qualify individuals to seek it.

The results of our study also complement the broader literature pertaining to women's candidate emergence. If we conceptualize the study of women's candidacies as a multistage endeavor, then over the course of the last 15 years, political scientists have provided compelling evidence that gender dynamics are at play at every stage. From the outset, some research finds that the lack of high-profile women in politics limits women's political engagement (see Burns, Schlozman, and Verba 2001; Campbell and Wolbrecht 2006). When we turn to the initial decision to run for office, gender differences also emerge. We demonstrate in previous work that female potential candidates are far less likely than their male counterparts to consider a candidacy or to emerge as actual candidates (Lawless and Fox 2010; 2005). Patterns of political recruitment regularly fuel the ambition of male candidates, but overlook that of female candidates (Crowder-Meyer 2013; Niven 1998; Sanbonmatsu 2006).

When potential candidates opt to throw their hats into the ring or seek high office, gender dynamics continue to play an important role. Women are more likely than men to emerge as candidates in "women friendly" districts, so they face geographic restrictions that male candidates generally do not confront (Palmer and Simon 2008). Women are also treated more hospitably by the Democratic party, which means that their electoral fate is linked more to the vagaries of the political climate than men's (see Thomsen 2012). Gender dynamics are apparent in the development of progressive ambition as well. That is, among state legislators, women and men have different perceptions about the desirability of serving in higher office (Fulton et al 2006). Women are also more likely than men to depart from Congress prematurely when they hit a "career ceiling" and can no longer affect the legislative agenda. And the women who depart voluntarily from Congress are less likely than similarly situated men to seek higher office (Lawless and Theriault 2005).

At all phases of the candidate emergence process, then, gender interacts and intersects with political ambition. But whereas previous research on the gender gap in political ambition focuses on how the gap manifests itself, our findings indicate that, starting at a young age, men's political interest, discussion, and ambition are piqued in a way that women's are not. Future research may want to home in on the college experience and the manner in which newfound independence exacerbates the gender disparity in political ambition. Scholars may also want to explore further the structural remedies that could alter the situation. Our results, working in concert with findings from other studies, suggest that recruitment efforts targeted toward women and campaign schools and training programs for female candidates are the best short-term remedy to counter the deeply embedded patterns of traditional gender socialization that contribute to the gender gap in political ambition. Of course, given gendered patterns of political recruitment, these structural remedies are contingent on electoral gatekeepers' deliberate and systematic efforts to change the status quo-efforts that have been fleeting throughout recent election cycles.

Ultimately, this study makes clear that we still have a long way to go before women and men will express equal interest in and comfort with the idea of running for office. Only by continuing to examine these gender differences in real time, as opposed to relying on retrospective assessments of events that occurred decades earlier, can we get at the source of the gender gapa gender gap that carries important implications for democratic legitimacy and political representation. 


\section{APPENDIX A. Sample Demographics}

\begin{tabular}{|c|c|c|c|c|c|c|}
\hline & \multicolumn{2}{|c|}{ Full Sample } & \multicolumn{2}{|c|}{ High School } & \multicolumn{2}{|c|}{ College } \\
\hline & Women & Men & Women & Men & Women & Men \\
\hline \multicolumn{7}{|l|}{ Party Affiliation } \\
\hline Democrat & $40 \%$ & $38 \%$ & $30 \%$ & $31 \%$ & $49 \% *$ & $43 \%$ \\
\hline Independent & 9 & 10 & 7 & 9 & 10 & 11 \\
\hline Republican & $23^{*}$ & 26 & 24 & 26 & $21^{*}$ & 26 \\
\hline Other or No political party affiliation & 27 & 25 & 38 & 34 & 20 & 20 \\
\hline \multicolumn{7}{|l|}{ Race } \\
\hline White & 62 & 62 & 67 & 68 & 58 & 56 \\
\hline Black & 12 & 11 & 11 & 9 & 13 & 12 \\
\hline Latino/Hispanic & 15 & 17 & 12 & 14 & 15 & 19 \\
\hline Other & 11 & 11 & 10 & 9 & 11 & 13 \\
\hline \multicolumn{7}{|l|}{ Region } \\
\hline Northeast & 17 & 20 & 18 & 20 & 16 & 19 \\
\hline Midwest & 25 & 25 & 26 & 28 & 24 & 23 \\
\hline South & $36 *$ & 31 & $35^{*}$ & 30 & $37^{*}$ & 32 \\
\hline West & 22 & 24 & 20 & 22 & 23 & 26 \\
\hline \multicolumn{7}{|l|}{ Estimated Household Income } \\
\hline Less than $\$ 50,000$ & $52^{*}$ & 46 & 38 & 35 & $62^{*}$ & 57 \\
\hline$\$ 50,000-\$ 99,999$ & $31^{*}$ & 35 & 40 & 41 & 25 & 29 \\
\hline$\$ 100,000-\$ 149,999$ & 11 & 13 & 15 & 16 & 8 & 10 \\
\hline At least $\$ 150,000$ & 5 & 7 & 7 & 8 & 5 & 4 \\
\hline \multicolumn{7}{|l|}{ Religion } \\
\hline Protestant & 37 & 34 & 43 & 41 & $33^{*}$ & 28 \\
\hline Catholic & 25 & 27 & 26 & 29 & 23 & 26 \\
\hline Jewish & 2 & 3 & 2 & 3 & 2 & 3 \\
\hline Muslim & 1 & 1 & 0 & 1 & 1 & 1 \\
\hline Mormon & 2 & 2 & 4 & 2 & 1 & 2 \\
\hline Other & 11 & 10 & 9 & 8 & 13 & 13 \\
\hline Not part of any religion & 22 & 24 & 16 & 18 & 27 & 29 \\
\hline \multicolumn{7}{|l|}{ Education } \\
\hline Currently in high school & 46 & 47 & 100 & 100 & 0 & 0 \\
\hline Currently in college & 55 & 53 & 0 & 0 & 100 & 100 \\
\hline Mean Age (Years) & 18 yrs. & 18 yrs. & 15 yrs. & 15 yrs. & 21 yrs. & $21 \mathrm{yrs}$. \\
\hline$N$ & 2,012 & 1,923 & 915 & 903 & 1,097 & 1,020 \\
\hline
\end{tabular}

Notes: Number of cases varies slightly, as some respondents omitted answers to some questions. Partisans include independent leaners. Levels of significance:* indicates that the gender gap is statistically significant at $p<.05$. 


\section{APPENDIX B. Variable Description}

\begin{tabular}{|c|c|c|c|c|}
\hline Variable & Range & Mean & $\begin{array}{l}\text { Standard } \\
\text { Deviation }\end{array}$ & Coding \\
\hline \multicolumn{5}{|c|}{ DEPENDENT VARIABLES } \\
\hline $\begin{array}{l}\text { Four-point ambition } \\
\text { scale }\end{array}$ & $1-4$ & 2.22 & .93 & $\begin{array}{l}\text { Indicates the extent to which the respondent is interested in running for political office in the future. } \\
\text { Scale ranges from would "never run for office" (1) to would "definitely like to run for office" (4). }\end{array}$ \\
\hline $\begin{array}{l}\text { At least open to running } \\
\text { for office }\end{array}$ & 0,1 & .42 & .49 & $\begin{array}{l}\text { Indicates whether the respondent would "definitely run for office" or is at least "open to the possibility" } \\
\text { of running for office in the future (1) or not }(0) \text {. }\end{array}$ \\
\hline \multicolumn{5}{|c|}{ INDEPENDENT VARIABLES - Family Socialization Expectation } \\
\hline $\begin{array}{l}\text { Parents encouraged a } \\
\text { candidacy }\end{array}$ & 0,1 & .32 & .47 & $\begin{array}{l}\text { Indicates whether at least one of the respondent's parents ever suggested that he/she run for office } \\
\text { in the future (1) or not (0). }\end{array}$ \\
\hline $\begin{array}{l}\text { Other family member } \\
\text { encouraged a } \\
\text { candidacy }\end{array}$ & 0,1 & .18 & .38 & $\begin{array}{l}\text { Indicates whether a family member (not including a parent) ever suggested that the respondent run } \\
\text { for office in the future (1) or not }(0) \text {. }\end{array}$ \\
\hline $\begin{array}{l}\text { Politicized household } \\
\text { growing up }\end{array}$ & $0-4$ & 1.10 & 1.08 & $\begin{array}{l}\text { Indicates the number of the following descriptions that characterize the respondent's household } \\
\text { while he/she was growing up: the news is often on; parents sometimes yell at the television } \\
\text { because they are so angry about politics; often talk about politics at meal times; parents often talk } \\
\text { about politics with friends and family. }\end{array}$ \\
\hline $\begin{array}{l}\text { Political activities with } \\
\text { parents }\end{array}$ & $0-6$ & 1.88 & 1.52 & $\begin{array}{l}\text { Indicates the number of the following political activities in which the respondent engaged with } \\
\text { parents: watched election coverage, discussed } 2012 \text { presidential election, discussed same-sex } \\
\text { marriage debate, discussed global warming/environment, discussed the wars in Iraq and } \\
\text { Afghanistan, shared a political story via email or through social media. }\end{array}$ \\
\hline \multicolumn{5}{|c|}{ INDEPENDENT VARIABLES - Political Context Expectation } \\
\hline $\begin{array}{l}\text { Political discussion in } \\
\text { classes }\end{array}$ & 2-8 & 5.53 & 1.57 & $\begin{array}{l}\text { Indicates how interested the respondent's peers at school are in politics and current events and the } \\
\text { extent to which these discussions occur in the classroom. Higher numbers indicate greater levels } \\
\text { of political interest and discussion at school. }\end{array}$ \\
\hline $\begin{array}{l}\text { Political discussion with } \\
\text { friends }\end{array}$ & $2-8$ & 5.26 & 1.82 & $\begin{array}{l}\text { Indicates how frequently the respondent discusses politics and current events with his/her friends. } \\
\text { Higher numbers indicate more political discussion. }\end{array}$ \\
\hline $\begin{array}{l}\text { Teacher encouraged a } \\
\text { candidacy }\end{array}$ & 0,1 & .13 & .33 & $\begin{array}{l}\text { Indicates whether a teacher or professor ever suggested that the respondent run for office in the } \\
\text { future (1) or not (0). }\end{array}$ \\
\hline $\begin{array}{l}\text { Civic education in high } \\
\text { school }\end{array}$ & $0-4$ & 1.29 & 1.11 & $\begin{array}{l}\text { Indicates the number of the following activities in which the respondent engaged while in high school: } \\
\text { attended an assembly with a politician as a speaker, contacted a political leader as a class } \\
\text { assignment, volunteered in the community as part of a class assignment, took a government class. }\end{array}$ \\
\hline $\begin{array}{l}\text { Time spent on political } \\
\text { websites }\end{array}$ & $1-4$ & 1.89 & 1.02 & $\begin{array}{l}\text { Indicates the frequency with which the respondent visits politics websites. Ranges from "rarely or } \\
\text { never" (1) to "every day" (4). }\end{array}$ \\
\hline \multicolumn{5}{|c|}{ INDEPENDENT VARIABLES - Competitive Experiences Expectation } \\
\hline $\begin{array}{l}\text { Ever ran for student } \\
\text { government }\end{array}$ & 0,1 & .22 & .41 & Indicates whether the respondent ever ran for a student government position (1) or not (0). \\
\hline $\begin{array}{l}\text { Participated in debate } \\
\text { or mock trial }\end{array}$ & 0,1 & & & $\begin{array}{l}\text { Indicates whether the respondent ever participated in a debate or a mock trial team/club (1) or not } \\
(0) \text {. }\end{array}$ \\
\hline $\begin{array}{l}\text { Leadership positions at } \\
\text { school }\end{array}$ & $0-15$ & .90 & 1.90 & Indicates the total number of leadership activities the respondent holds (from a list of 15 activities). \\
\hline $\begin{array}{l}\text { Competitiveness } \\
\text { playing sports }\end{array}$ & $1-4$ & 2.75 & 1.09 & $\begin{array}{l}\text { Indicates the respondent's level of competitiveness associated with sports. Ranges from never } \\
\text { played a sport (1) to "very competitive and winning is very important" (4). }\end{array}$ \\
\hline
\end{tabular}




\section{APPENDIX B. Continued}

\begin{tabular}{|c|c|c|c|c|}
\hline Variable & Range & Mean & $\begin{array}{l}\text { Standard } \\
\text { Deviation }\end{array}$ & Coding \\
\hline \multicolumn{5}{|c|}{ INDEPENDENT VARIABLES - Self-Confidence Expectation } \\
\hline $\begin{array}{l}\text { Self-assessment of } \\
\text { qualifications to run }\end{array}$ & $1-3$ & 1.79 & .69 & $\begin{array}{l}\text { Indicates whether the respondent believes that when he/she has finished school and has been } \\
\text { working for a while, he/she will be prepared and know enough to run for office. Higher numbers } \\
\text { indicate a greater sense that the respondent will be qualified to run for office. }\end{array}$ \\
\hline Political traits index & $0-4$ & 2.37 & 1.14 & $\begin{array}{l}\text { Indicates the number of the following traits the respondent self-assesses as possessing: confident, } \\
\text { assertive, friendly, smart. }\end{array}$ \\
\hline Political skills index & $0-5$ & 2.14 & 1.33 & $\begin{array}{l}\text { Indicates the number of the following skills and qualifications the respondent contends he/she } \\
\text { possesses: good writer, good at public speaking, knows a lot about politics, usually good at most } \\
\text { things, willing to try new things. }\end{array}$ \\
\hline \multicolumn{5}{|c|}{ INDEPENDENT VARIABLES - Gender Roles \& Identity Expectation } \\
\hline Women's roles index & $3-12$ & 6.30 & 1.66 & $\begin{array}{l}\text { Indicates the extent to which the respondent agrees that "It's best when a mother stays home and } \\
\text { takes care of the children rather than works;" "When a husband and wife disagree, it is best if the } \\
\text { wife lets the husband decide;" and "It's fine for girls to make the first move and ask someone they } \\
\text { like out on a date." Index was created so that higher scores indicate more traditional gender roles } \\
\text { and attitudes. }\end{array}$ \\
\hline $\begin{array}{l}\text { Political jobs } \\
\text { stereotypes index }\end{array}$ & $0-2$ & .39 & .67 & $\begin{array}{l}\text { Indicates whether the respondent believes that men would make better senators and presidents than } \\
\text { women. The respondent could stereotype on neither position (0), one political position (1), or both } \\
\text { positions (2). }\end{array}$ \\
\hline Female role model & 0,1 & .80 & .40 & $\begin{array}{l}\text { Indicates whether the respondent relies on any of the following for inspiration about what to do in the } \\
\text { future: mother, other female family member, female friend, female teacher, female professor, } \\
\text { female coach, female boss, female religious figure. }\end{array}$ \\
\hline \multicolumn{5}{|c|}{ INDEPENDENT VARIABLES - Controls } \\
\hline Sex (female) & 0,1 & .51 & .50 & Indicates whether the respondent is female (1) or male (0). \\
\hline Black & 0,1 & .11 & .32 & Indicates whether the respondent is Black (1) or not $(0)$. \\
\hline Latino & 0,1 & .16 & .37 & Indicates whether the respondent is Latino/a (1) or not $(0)$ \\
\hline Democrat & 0,1 & .39 & .49 & Indicates whether the respondent identifies as a Democrat (1) or not (0). This includes leaners. \\
\hline Republican & 0,1 & .24 & .43 & Indicates whether the respondent identifies as a Republican (1) or not (0). This includes leaners. \\
\hline Income & $1-19$ & 10.87 & 4.78 & $\begin{array}{l}\text { Indicates the respondent's household income, ranging from less than } \$ 5,000 \text { (1) to at least } \$ 175,000 \\
\text { (13). }\end{array}$ \\
\hline Age & $13-25$ & 18.17 & 3.52 & Indicates the respondent's age. \\
\hline South & 0,1 & .34 & .47 & Indicates whether the respondent lives in the South (1) or not (0). \\
\hline Sample & 1,2 & 1.54 & .99 & Indicates whether the respondent is a high school (1) or college (2) student. \\
\hline Political activity index & $0-8$ & 2.02 & 1.77 & $\begin{array}{l}\text { Indicates the number of the following eight political activities in which the respondent engaged: voted } \\
\text { in a student election, attended a rally or protest, helped raise money for a cause or campaign, } \\
\text { blogged or emailed about a political issue, posted something about politics using social media, } \\
\text { volunteered in the community, followed a political figure on a social media site, volunteered on a } \\
\text { political campaign. }\end{array}$ \\
\hline
\end{tabular}




\section{APPENDIX C. The Gender Gap in Political Ambition among High School versus College Students}

Our examination of the size of the gender gap by respondent age indicates that grouping the data by high school and college students is an appropriate way to conduct the analysis. There is very little variation during the high school years (all high school respondents were between the ages of 13 and 17). For three of the five ages in the high school sample, there is virtually no gender difference in considering a candidacy; for two of the years (ages 15 and 17), there are gender gaps. The data reveal, however, that there is no discernible pattern and that the changes in the size of the gap are not linear.

The gender gap is much more dramatic in college, and this seems to be the case from early in the college experience. Again, although there are some fluctuations in the size of the gap between the ages of 18 and 25, for six of the eight ages within the college subsample, the gender gap is at least 22 percentage points. And although it is smaller for 19 and 21 year olds, there is, once again, no systematic pattern to account for these differences.

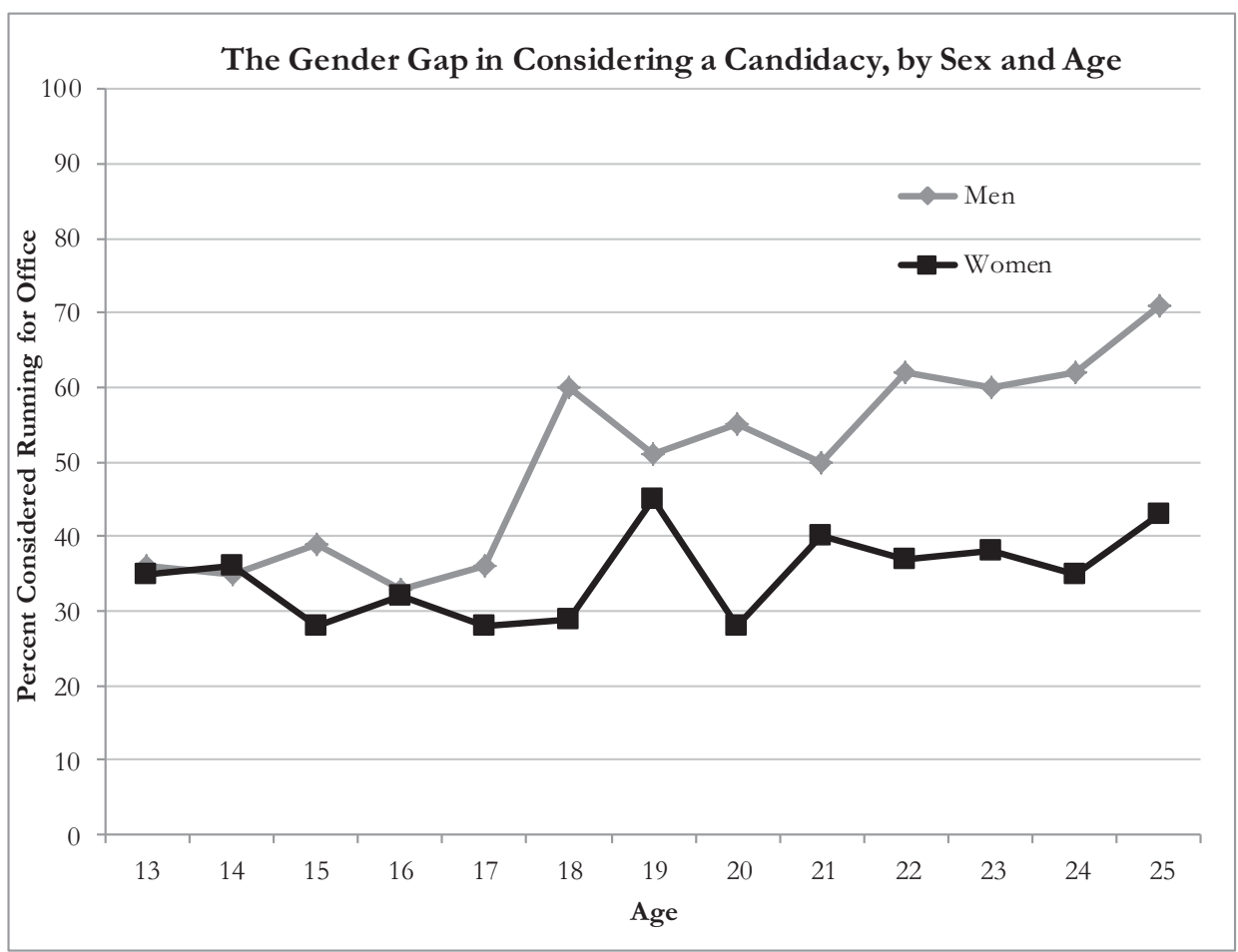




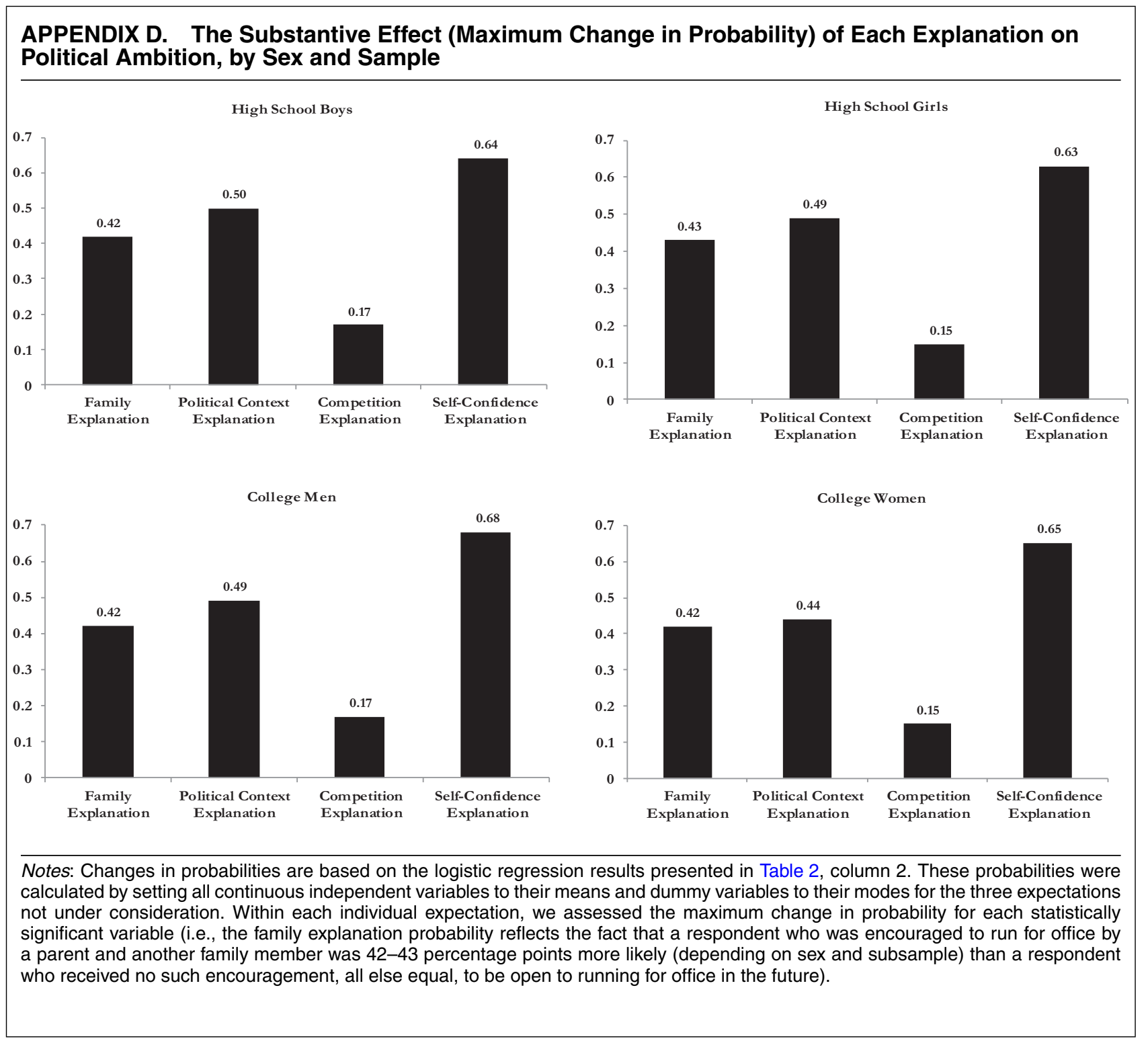

\section{REFERENCES}

Ahn, T. K., Robert Huckfeldt, and John B. Ryan. 2010. "Communication, Influence, and Informational Asymmetries among Voters." Political Psychology 31(5): 763-87.

Alford, John, Carolyn L. Funk, and John R. Hibbing. 2005. “Are Political Orientations Genetically Transmitted?" American Political Science Review 99(2): 153-67.

American Political Science Association. 2010. "Political Science Enrollment, Degrees, Majors." Accessed at: http://www.apsanet. org/media/dsp/NSF\%20Science \%20and\%20Engineering \%20BA $\% 20$ Degrees $\% 20$ Awarded $\% 20$ by $\% 20$ degree $\% 20$ and $\% 20$ sex $\%$ 2019662008.pdf. (July 5, 2013).

Andolina, Molly W., Krista Jenkins, Cliff Zukin, and Scott Keeter. 2003. "Habits from Home, Lessons from School: Influences on Youth Civic Engagement." PS: Political Science \& Politics 36(2): 275-80.

Armstrong, Elizabeth A., Laura Hamilton, and Brian Sweeney. 2006. "Sexual Assault on Campus: A Multilevel, Integrative Approach to Party Rape." Social Problems 53(4): 483-99.

Ashby, Julie S., and Ingrid Schoon. 2010. "Career Success: The Role of Teenage Career Aspirations, Ambition Value and Gender in
Predicting Adult Social Status and Earnings.” Journal of Vocational Behavior 77(3): 350-60.

Atkeson, Lonna Rae. 2003. "Not All Cues Are Created Equal: The Conditional Impact of Female Candidates on Political Engagement." Journal of Politics 65(4): 1040-61.

Barron, John M., Bradley T. Ewing, and Glen R. Waddell. 2000. "The Effects of High School Athletic Participation on Education and Labor Market Outcomes." Review of Economics and Statistics 82(3): 409-42.

Beloff, Halla. 1992. "Mother, Father and Me: Our IQ." Psychologist 5: 309-11.

Billig, Shelley, Sue Root, and Dan Jesse. 2005. "The Impact of Participation in Service-Learning on High School Students' Civic Engagement." College Park: Center for Information and Research on Civic Learning and Engagement.

Brown, Gary. 2012. "NCAA Student-Athlete Participation Hits 450,000." Indianapolis: National Collegiate Athletic Association. Accessed at: http://www.ncaa.org/wps/wcm/connect/public/ NCAA/Resources/Latest \pm News/2012/September/NCAA \pm student-athlete \pm participation \pm hits \pm 450000 (September 3, 2013). Burns, Nancy, Kay Lehman Schlozman, and Sidney Verba. 2001. The Private Roots of Public Action: Gender, Equality, and 
Political Participation. Cambridge, MA: Harvard University Press.

Campbell, David E. 2008. "Voice in the Classroom: How an Open Classroom Climate Fosters Political Engagement among Adolescents." Political Behavior 30(4): 437-54.

Campbell, David E., and Christina Wolbrecht. 2006. "See Jane Run: Women Politicians as Role Models for Adolescents." Journal of Politics 68(1): 233-247.

Canon, David T. 1993. "Sacrificial Lambs or Strategic Politicians? Political Amateurs in the U.S. Elections." American Journal of Political Science 37(4):1119-41.

Carroll, Susan J. 1994. Women as Candidates in American Politics. 2nd ed. Bloomington: Indiana University Press.

Charney, Evan, and William English. 2012. "Candidate Genes and Political Behavior." American Political Science Review 106(1): 134

Crowder-Meyer, Melody. 2013. "Gendered Recruitment without Trying: How Local Party Recruiters Affect Women's Representation." Politics \& Gender 9(3): 390-413.

Dey, Eric L. 1996. "Undergraduate Political Attitudes: An Examination of Peer, Faculty, and Social Influences." Research in Higher Education 37: 535-54.

Devos, Thierry, Karla Blanco, Francisca Rico, and Roger Dunn 2008. "The Role of Parenthood and College Education in the SelfConcept of College Students: Explicit and Implicit Assessments of Gendered Aspirations." Sex Roles 59(3-4): 214-28.

Dickson, Lisa. 2010. "Race and Gender Differences in College Major Choice." The ANNALS of the American Academy of Political and Social Science 627(1): 108-24.

Dolan, Kathleen. 2006. "Symbolic Mobilization? The Impact of Candidate Sex in American Elections." American Politics Research 34(6): 687-704.

Elder, Laurel. 2004. "Why Women Don’t Run.” Women \& Politics 26(2): 27-56

Enloe, Cynthia. 2004. The Curious Feminist. Berkeley: University of California Press.

Erkut, Sumru, Jacqueline P. Fields, Rachel Sing, and Fern Marx. 1996. "Diversity in Girls' Experiences: Feeling Good about Who You Are." In Urban Girls: Resisting Stereotypes, Creating Identities, eds. Bonnie J. Ross Leadbeater and Niobe Way. New York: New York University Press.

Ewing, Bradley T. 2007. "The Labor Market Effects of High School Athletic Participation: Evidence from Wage and Fringe Benefit Differentials." Journal of Sports Economics 8(3): 255-65.

Fiorina, Morris P. 1981. Retrospective Voting in American National Elections. New Haven: Yale University Press.

Flammang, Janet. 1997. Women's Political Voice: How Women Are Transforming the Practice and Study of Politics. Philadelphia: Temple University Press.

Fowler, James H., Laura A. Baker, and Christopher T. Dawes. 2008 "Genetic Variation in Political Participation." American Political Science Review 102(2): 233-48

Fox, Richard L., and Jennifer L. Lawless. 2011. "Gendered Perceptions and Political Candidacies: A Central Barrier to Women's Equality in Electoral Politics." American Journal of Political Science 55(1): 59-73.

Freedman, Estelle. 2002. No Turning Back. New York: Ballantine Books.

Fuller, Jill. 2004. "Equality in Cyberdemocracy? Gauging Gender Gaps in On-Line Civic Participation." Social Science Quarterly 85(4): 939-57.

Fulton, Sarah A., Cherie D. Maestas, L. Sandy Maisel, and Walter J. Stone. 2006. "The Sense of a Woman: Gender, Ambition and the Decision to Run for Congress." Political Research Quarterly 59(2): 235-48.

Furnham, Adrian, and Richard Rawles. 1995. "Sex Differences in the Estimation of Intelligence." Journal of Social Behavior and Personality 10: 741-48.

Gaddie, Ronald Keith. 2004. Born to Run: Origins of the Political Career. Lanham: Rowman and Littlefield.

Gerrity, Jessica C., Tracy Osborn, and Jeanette Morehouse Mendez. 2007. "Women and Representation: A Different View of the District?" Politics \& Gender 3(2): 179-200.

Glanville, Jennifer L. 1999. "Political Socialization or Selection? Adolescent Extracurricular Participation and Political Activity in Early Adulthood." Social Science Quarterly 80(2): 279-90.
Gmelch, Sharon Bohn. 1998. Gender on Campus: Issues for College Women. New Brunswick, NJ: Rutgers University Press.

Gneezy, Uri, Muriel Niederle, and Aldo Rustichini. 2003. "Performance in Competitive Environments: Gender Differences." Quarterly Journal of Economics 118(3): 1049-74.

Hansen, Susan B. 1997. "Talking About Politics: Gender and Contextual Effects on Political Proselytizing." Journal of Politics 59(1): 73-103.

Hart, Daniel, Thomas M. Donnelly, James Youniss, and Robert Atkins. 2007. "High School Community Service as a Predictor of Adult Voting and Volunteering." American Education Research Journal 44(1): 197-219.

Hegewisch, Ariane, Hannah Liepmann, Jeff Hayes, and Heidi Hartmann. 2010. Separate and Not Equal? Gender Segregation in the Labor Market and the Gender Wage Gap. Washington, DC: Institute for Women's Policy Research.

Hillygus, D. Sunshine. 2005. "The Missing Link: Exploring the Relationship between Higher Education and Political Engagement." Political Behavior 27(1): 25-47.

Howard, Bruce, and John Gillis. 2009. "High School Sports Participation Increases for $20^{\text {th }}$ Consecutive Year." Indianapolis: National Federation of State High School Associations. Accessed at: http://www.nfhs.org/content.aspx?id=3505 (September 3, 2013).

Huckfeldt, Robert, and Jeanette Morehouse Mendez. 2008. "Moths, Flames, and Political Engagement: Managing Disagreement within Communication Networks." Journal of Politics 70(1): 83-96.

Interparliamentary Union. 2013. "Women in National Parliaments." Accessed at: http://www.ipu.org/wmn-e/world.htm (September 20, 2013).

Iyengar, Shanto, and Simon Jackman. 2004. "Technology and Politics: Incentives for Youth Participation." College Park: Center for Information and Research on Civic Learning and Engagement.

Jackson, Carolyn. 2003. "Transitions into Higher Education: Gendered Implications for Academic Self-Concept." Oxford Review of Education 29(3): 331-46.

Jennings, M. Kent. 2002. "Generation Units and the Student Protest Movement in the United States: An Intra- and Intergenerational Analysis." Political Psychology 23: 303-24.

Jennings, M. Kent. 2007. "Political Socialization." In The $O x$ ford Handbook of Political Behavior, eds. Russell J. Dalton and Hans-Dieter Klingemann. New York: Oxford University Press.

Jennings, M. Kent, and Gregory B. Markus. 1984. "Partisan Orientations over the Long Haul: Results from the Three-Wave Political Socialization Panel Study." American Political Science Review 78(4): 1000-18.

Jennings, M. Kent, and Laura Stoker. 2012. "Continuities in Political Participation across Generations." Unpublished manuscript.

Jennings, M. Kent, Laura Stoker, and Jake Bowers. 2009. "Politics across Generations: Family Transmission Reexamined." Journal of Politics 71(3): 782-99.

Kahne, Joseph E., and Susan E. Sporte. 2008. "Developing Citizens: The Impact of Civic Learning Opportunities of Students' Commitment to Civic Participation." American Educational Research Association 45(3): 738-66.

Kathlene, Lyn. 1994. "Power and Influence in State Legislatures: The Interaction of Gender and Position in Committee Hearing Debates." American Political Science Review 88(3): 56076.

Kirlin, Mary. 2003. "The Role of Adolescent Extra-Curricular Activities in Adult Political Participation." College Park: Center for Information and Research on Civic Learning and Engagement.

Kling, Kristen C., Janet Hyde, Carolin Showers, and Brenda N. Buswell. 1999. "Gender Differences in Self-Esteem: A Meta-Analysis." Psychological Bulletin 125(4): 470-500.

Lawless, Jennifer L. 2004. "Politics of Presence: Women in the House and Symbolic Representation." Political Research Quarterly 57(1): 81-99.

Lawless, Jennifer L., and Richard L. Fox. 2005. It Takes a Candidate: Why Women Don't Run for Office. New York: Cambridge University Press.

Lawless, Jennifer L., and Richard L. Fox. 2010. It Still Takes a Candidate: Why Women Don't Run for Office. New York: Cambridge University Press.

Lawless, Jennifer L., and Richard L. Fox. 2012. Men Rule: The Continued Under-Representation of Women in U.S. Politics. Washington, DC: Women \& Politics Institute. 
Lawless, Jennifer L. and Sean M. Theriault. 2005. "Will She Stay or Will She Go? Career Ceilings and Women's Retirement from the U.S. Congress." Legislative Studies Quarterly 30(4): 581-96.

Lechner, Michael. 2009. "Long-Run Labour Market and Health Effects of Individual Sports Activities." Journal of Health Economics 28(4): 839-54.

Maestas, Cherie D., Sarah Fulton, L. Sandy Maisel, and Walter J. Stone. 2006. "When to Risk It? Institutions, Ambitions, and the Decision to Run for the U.S. House." American Political Science Review 100(2): 195-208.

Mansbridge, Jane. 1999. "Should Blacks Represent Blacks and Women Represent Women? A Contingent 'Yes'." Journal of Politics 61(3): 628-57.

Marks, Helen, and Susan Robb Jones. 2004. "Community Service in the Transition: Shifts and Continuities in Participation from High School to College." Journal of Higher Education 75(3): 307-39.

Marks, Jaime, Lam Chun Bun, and Susan M. McHale. 2009. "Family Patterns of Gender Role Attitudes." Sex Roles 61(3-4): 221-34.

Markus, Gregory B. 1986. "Stability and Change in Political Attitudes: Observed, Recalled, and Explained." Political Behavior 8: 21-44.

Marx, David M., and Jasmin S. Romin. 2002. "Female Role Models: Women's Math Test Performance.” Personal Social Psychology Bulletin 28: 1183-93.

McClurg, Scott D., Michelle L. Wade, and Maja V. Wright-Phillips. 2013. "He Said, She Said: Sex, Social Networks, and Voting Behavior." American Politics Research 41(6): 1102-13.

McFarland, Daniel A., and Reuben J. Thomas. 2006. "Bowling Young: How Youth Voluntary Associations Influence Adult Political Participation." American Sociological Review 71(3): 401-25.

McIntosh, Hugh, Daniel Hart, and James Youniss. 2007. "The Influence of Family Political Discussion on Youth Civic Development: Which Parent Qualities Matter?" PS: Political Science \& Politics 40(3): 495-99.

Mello, Zena R., 2008. "Gender Variation in Developmental Trajectories of Educational and Occupational Expectations and Attainment from Adolescence to Adulthood." Developmental Psychology 44(4): 1069-80.

Mendez, Jeanette Morehouse, and Tracy Osborn. 2010. "Gender and the Perception of Knowledge in Political Discussion." Political Research Quarterly 63(2): 269-79.

Montgomery, Kathryn, Barbara Gottlieb-Robles, and Gary O. Larson. 2004. Youth as E-Citizens: Engaging the Digital Generation. Washington, DC: Center for Social Media, American University.

Niederle, Muriel, and Lise Vesterlund. 2007. "Do Women Shy Away from Competition? Do Men Compete Too Much?" Quarterly Journal of Economics 122(3): 1067-1101.

Niven, David. 1998. The Missing Majority: The Recruitment of Women as State Legislative Candidates. Westport: Praeger.

Nixon, Lucia A., and Michael D. Robinson. 1999. "The Educational Attainment of Young Women: Role Model Effects of Female High School Faculty." Demography 36(2): 185-94.

Osborn, Tracy, and Jeanette Morehouse Mendez. 2010. "Speaking as Women: Women and Floor Speeches in the Senate." Journal of Women, Politics \& Policy 31(1): 1-21.

Pajares, Frank. 2002. "Gender and Perceived Self-Efficacy in SelfRegulated Learning." Theory Into Practice 41(2): 116-25.

Palmer, Barbara, and Dennis Simon. 2008. Breaking the Political Glass Ceiling: Women and Congressional Elections. 2nd ed. New York: Routledge.

Pasek, Josh, Lauren Feldman, Daniel Romer, and Kathleen Hall Jamieson. 2008. "Schools as Incubators of Democratic Participation: Building Long-Term Political Efficacy with Civic Education." Applied Developmental Science 12(1): 26-37.

Roberts, T. 1991. "Gender and the Influences of Evaluation on Self-Assessment in Achievement Settings." Psychological Bulletin 109(2): 297-308

Rohde, David W. 1979. "Risk-Bearing and Progressive Ambition: The Case of the U.S. House of Representatives." American Journal of Political Science 23(1): 1-26.

Rosenthal, Cindy Simon. 1998. When Women Lead. New York: Oxford University Press.

Ryan, John Barry. 2011. "Social Networks as a Shortcut to Correct Voting." American Journal of Political Science 55(4): 753-66.
Sallie Mae. 2012. "How America Pays for College 2012." Accessed at: https://www.salliemae.com/assets/Core/how-America-pays/ HowAmericaPays2012.pdf. (July 19, 2013).

Sanbonmatsu, Kira. 2006. Where Women Run: Gender and Party in the American States. Ann Arbor: University of Michigan Press.

Sapiro, Virginia. 2004. "Not Your Parents' Political Socialization: Introduction for a New Generation." Annual Review of Political Science 7: 1-23.

Schacter, Daniel L. 1999. "The Seven Sins of Memory: Insights from Psychology and Cognitive Neuroscience." American Psychologist 54: $182-203$

Schacter, Daniel L., Joan Y. Chiao, and Jason P. Mitchell. 2003. "The Seven Sins of Memory: Implications for the Self." In The Self: From Soul to Brain, eds. Joseph LeDoux, Jacek Debiece, and Henry Moss. New York: Annals of the New York Academy of Sciences.

Sigelman, Lee, and Clyde Wilcox. 2001. "Public Support for Gender Equality in Athletics Programs." Women \& Politics 22(1): 85-96.

Smith, Elizabeth. 1999. "The Effects of Investments in the Social Capital of Youth on Political and Civic Behavior in Young Adulthood: A Longitudinal Analysis." Political Psychology 20(3): 55380

Stevenson, Betsey. 2010. "Beyond the Classroom: Using Title IX to Measure the Return to High School Sports." Review of Economics and Statistics 92(2): 284-301.

Stoker, Laura, and Jackie Bass. 2011. "Political Socialization: Ongoing Questions and New Directions." In The Oxford Handbook of American Public Opinion and the Media, eds. Robert Y. Shapiro and Lawrence R. Jacobs. New York: Oxford University Press.

Stone, Linda, and Nancy P. McKee. 2000. "Gendered Futures: Student Visions of Career and Family on a College Campus." Anthropology \& Education Quarterly 31(1): 67-89.

Stone, Walter J., and L. Sandy Maisel. 2003. "The Not-So-Simple Calculus of Winning: Potential U.S. House Candidates' Nominations and General Election Prospects." Journal of Politics 65(4) 951-77.

Stuber, Jenny M., Joshua Klugman, and Caitlin Daniel. 2011. "Gender, Social Class, and Exclusion: Collegiate Peer Cultures and Social Reproduction." Sociological Perspectives 54(3): 431-51.

Swers, Michele L. 2002. The Difference Women Make. Chicago: University of Chicago Press.

Thomas, Sue. 1994. How Women Legislate. New York: Oxford University Press.

Thomsen, Danielle M. 2012. "Partisan Polarization and the Representation of Women in the U.S. Congress." Paper presented at the annual meeting of the American Political Science Association. New Orleans: September 1-4.

Tolleson-Rinehart, Sue. 1992. Gender Consciousness and Politics. New York: Routledge.

Trice, Ashton D., and Nancy McClellan. 1993. "Do Children's Career Aspirations Predict Adult Occupations? An Answer from a Secondary Analysis of a Longitudinal Study." Psychological Reports 72: $368-70$

Verba, Sidney, Key Lehman Schlozman, and Henry E. Brady. 1995. Voice and Equality: Civic Voluntarism in American Politics. Cambridge: Harvard University Press.

Verba, Sidney, Kay Lehman Schlozman, and Nancy Burns. 2005. "Family Ties: Understanding the Intergenerational Transmission of Political Participation." In The Social Logic of Politics, ed. Alan S. Zuckerman. Philadelphia: Temple University Press.

Walker, Edward T. 2008. "Contingent Pathways from Joiner to Activist: The Indirect Effect of Participation in Voluntary Associations on Civic Engagement." Sociological Forum 23(1): 116-43.

Weikart, Lynne A., Greg Chen, Daniel W. Williams, and Haris Hromic. 2007. "The Democratic Sex: Gender Differences and the Exercise of Power." Women, Politics \& Policy 28(1): 11940.

Wigfield, Allan, Jacquelynne S. Eccles, and Paul R. Pintrich. 1996. "Development between the Ages of 11 and 25." In Handbook of Educational Psychology, eds. D.C. Berliner and R.C. Calfee. New York: Macmillan.

Wolak, Jennifer, and Michael McDevitt. 2011. "The Roots of the Gender Gap in Political Knowledge in Adolescence." Political Behavior 33(3): 505-33. 